\title{
Geochemical Baselines of Stream and Spring Waters From Areas Underlain by Permian and Pennsylvanian Rocks, Including Evaporites, and Potential Environmental Damage in the Eagle Valley, Colorado
}

by William R. Miller ${ }^{1}$

Open-File Report 01-362

2001

This report is preliminary and has not been reviewed for conformity with the U.S. Geological Survey editorial standards and stratigraphic nomenclature. Any use of trade product or firm names is for descriptive purposes only and does not imply endorsement by the U.S. Government.

U.S. DEPARTMENT OF THE INTERIOR U.S. GEOLOGICAL SURVEY

${ }^{1}$ Denver, Colorado 


\section{Introduction}

When precipitation, as rain and snow, falls within a watershed, water comes into contact with rock minerals and chemical weathering is initiated. These processes release elements to the natural waters of a watershed. Therefore the chemical composition of natural waters that evolve within a watershed, in the absence anthropogenic input, is determined mostly by the chemical composition of rocks within the basin. Other factors such as rates of mechanical erosion, grain size and crystallinity of the rock minerals, amount and distribution of precipitation, temperature, type and amount of vegetation, and biota activity influence mainly the rates of the water-rock reactions, but the chemical composition of the rocks is the fundamental factor which determines the type of waters which evolve within a headwater watershed (Miller, 1999). This natural baseline geochemistry of waters of a watershed can be modified by input from anthropogenic processes which are always superimposed on the background geochemistry. The distribution of water available in streams and springs in these headwater watersheds is uneven throughout the year in western Colorado with high flows during the spring runoff and after summer thunderstorms. In the winter, water available in streams and springs reaches a minimum when element concentrations are high but mass flux is low. At this time, runoff is fed mainly by the recession of the groundwater reservoir. Geochemical baselines, at a particular point in time, can be determined for stream and spring waters in these headwater watersheds, and may approximate the background geochemistry. Because water geochemistry is sensitive to changes in the environment, by monitoring water geochemistry in these watersheds and comparing the results to the earlier geochemical baseline data, changes within the watershed can be detected.

The purpose of this study is to determine the baseline range of species and other geochemical parameters in order to characterize the baseline geochemistry of stream and spring waters evolving within headwater watersheds underlain by Permian and Pennsylvanian rocks which occur in western Colorado and often contain highly soluble evaporite minerals. Processes responsible for the control and mobility of species in the natural waters were also investigated as well as potential environmental damage associated with development of golf courses, homes, and 
ski areas on the Evaporite Facies rocks in Eagle Valley.

\section{Study Area}

The study areas occur within western Colorado (fig. 1) in the Southern Rocky Mountain physiographic province (Hunt, 1974). The mountain ranges and intermountain basins generally trend north-northwest. Dendritic drainage patterns are well developed and most of the area is of moderate to high relief. Several peaks are above 14,000 feet and the lowest point is around 6,500 feet along the Arkansas River. Annual precipitation ranges from as little as 10 inches near Antereo Reservoir in South Park to more than 40 inches in the higher Flat Tops area (Colorado Climate Center, 1984). Snow-melt runoff usually occurs from April through July and peaks in May through June (Apodaca and others, 1996).

Because of the large differences in altitude, the climate in the study area varies from coolhumid in the higher mountains to semi-arid in the lower elevations. The natural vegetation in the study area is strongly zoned by altitude. The vegetation in the subalpine zone is dominated by spruce and fir, the montane zone by pine and Douglas fir, which can alternate with juniperpinyon woodland, and mountain mahogany - scrub oak. Unforested mountain parks dominated by grasses and sometimes sagebrush and other shrubs are also present (U.S. Dept. of Agriculture, 1972).

\section{Geological History of the Permian and Pennsylvanian Rocks}

Permian and Pennsylvanian rocks in Colorado were formed during a series of continental collisions that resulted in deformation and uplift. The Ancestral Rocky Mountains formed around 300 mya probably as the result of the collision of North America with South AmericaAfrica along the southern margin of North America (Curtis, 1958). Tectonic activities consisted of block-fault mountain uplifts and subsiding basins between the uplifts. The Ancestral Rocky Mountains formed along two belts. The eastern belt is known as the ancestral Front Range uplift and the western belt as the Uncompahgre uplift. During the early stages of tectonic activities, 


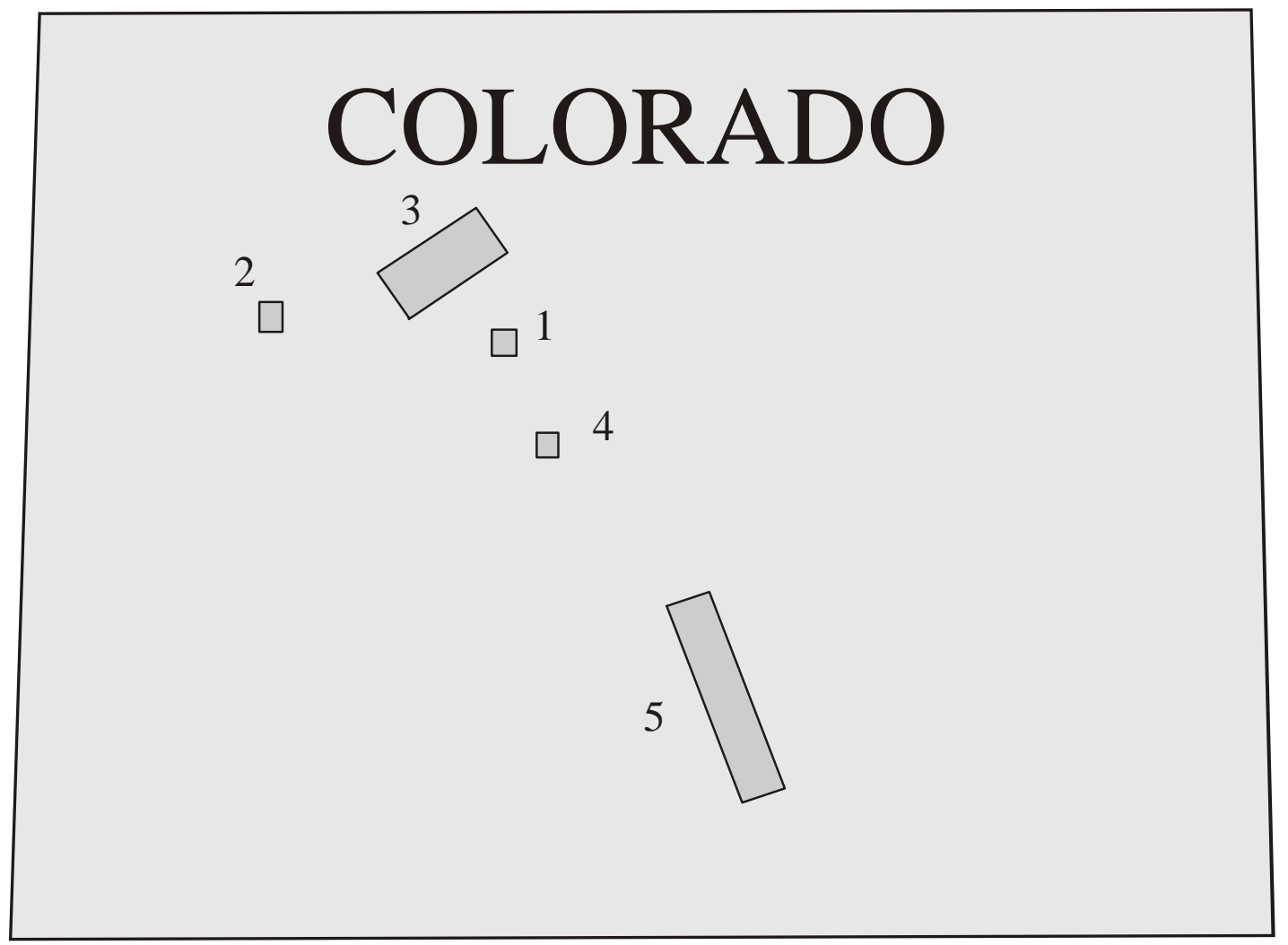

Figure 1. Location of study areas: 1) Redcliff area; 2) Flat Tops Area 3) Eagle Valley area; 4) South Park area; 5) Sangre de Cristo area. 
shallow seas invaded the basins and deposited marine sediments from the adjoining mountain uplifts. One of the large basins, the central Colorado trough, extended from northwest Colorado to south-central Colorado and contains between 10,000 to 20,000 feet of Permian and Pennsylvanian rocks of both marine and nonmarine origin (DeVoto, 1972). The earliest basindeposited sediments of Pennsylvanian age in the central Colorado trough are marine-transitional black shales and sandstone of the Belden Formation. The Minturn Formation and the younger Maroon Formation overlies the Belden Formation and consist of marine and nonmarine sediments accumulated adjacent to the basin margins but pass into evaporite and clastic deposits of the Eagle Valley Evaporite in the center of the basin (Mallory,1971). The Eagle Valley Evaporite between the towns of Avon and Gypsum, consists of a thick sequence of interbedded gypsum, anhydrite, halite, black shale and siltstone formed by evaporation of a narrow seaway.

Along the flanks of the Ancestral Rockies, sediments derived from the eroding mountain uplifts accumulated as valley fill and alluvial fans consisting of arkosic gravels and sands and conglomerates, predominately red in color (redbeds). In south-central Colorado, the Sangre de Cristo Formation of sandstones, conglomerates, and shales was deposited on mudflats with stream channels. The erosion of the Ancestral Rockies and the deposition of sediments in the basins continued into Permian time. By middle Permian time, terrestrial sedimentation had decreased and shallow seas invaded the region.

Evaporite minerals, particularly gypsum, are known to occur in the Pennsylvanian and Permian rocks throughout central Colorado. Gypsum is mined from the central Colorado trough near the town of Gypsum and along the Arkansas River below Salida, Colorado.

\section{Methods}

Generally small streams were sampled, usually with a watershed area of around several square miles, although some watersheds are larger. Springs within the watershed were also sampled. Waters were collected from five rock groups of Permian and Pennsylvanian age in western Colorado. The five rock groups are: 1) Pennsylvanian Minturn and Belden Formations in the Redcliff area, 2) Pennsylvanian Minturn and Belden Formations in the Flat Tops area; 3) 
Pennsylvanian Minturn and Belden Formations in the Sangre de Cristo Range; 4) Permian and Pennsylvanian Sangre de Cristo Formation in the Sangre de Cristo Range; and 5) Pennsylvanian Eagle Valley Formation, Evaporitic Facies in Eagle Valley and Evaporitic Facies of Minturn and Belden Formations in South Park (Tweto, 1979). The last group is from two areas but because all contain evaporite facies minerals, the two areas are combined and will be referred to as Evaporite Facies of Eagle Valley and South Park. Samples of water were collected from 36 streams and 9 spring sites from July 18 to August 24, 2000. The waters were collected after peak runoff had occurred but prior to the streams reaching base flow or in some cases, drying up completely. Generally, during the time of sampling, the weather was stable and no precipitation occurred. Waters from each of the study areas were usually collected within one or two days. Waters from areas of lower elevations were collected earlier in the season than the higher areas. During the time of sampling, the weather was stable and no precipitation occurred. Samples were collected by width and depth integration (Edwards and Glysson, 1988) or from a point source for springs. Temperature, $\mathrm{pH}$, and conductivity were measured at the site. $\mathrm{pH}$ was measured using an Orion model $250 \mathrm{pH}$ meter with an Orion Ross Sure-Flow electrode. Temperature was measured using temperature probe. The conductivity was measured using an Orion model 120 conductivity meter. Samples were collected into high-density polyethylene bottles. For the dissolved cation analyses, a sample was filtered at the site through a $0.45 \mu \mathrm{m}-$ membrane filter and acidified with ultrapure reagent-grade Ultrex nitric acid to $\mathrm{pH}<2$. Another sample was filtered but not acidified for anion analyses and an unfiltered, unacidified sample was collected for alkalinity measurement. The samples were stored in an ice chest and later in a refrigerator and kept cool until analyzed.

Upon return to the laboratory, alkalinity as $\mathrm{HCO}_{3}{ }^{-}$, was determined by titration with $\mathrm{H}_{2} \mathrm{SO}_{4}$ using Gran's plot technique (Orion Research, Inc.,1978). Sulfate, chloride, nitrate, and fluoride concentrations were determined by ion chromatography (IC) (Fishman and Pyen, 1979). Cations were analyzed by inductively coupled plasma - mass spectromentry (ICP-MS) or inductively coupled plasma - atomic emission spectrometry (ICP-AES). IC, ICP-AES, and alkalinity analyses were performed by Murdock Environmental Laboratory, University of Montana, Missoula, The ICP-MS analyses were determined by U.S.G.S. laboratories in Denver 
under the direction of Allen Meier. Duplicate water samples, blank samples, and USGS Water Resource Division standard reference waters were analyzed with each data set. The chemical analyses with date of collection, location, rock type of basin, water type, flow data, and comments are shown for all sites in appendix 1.

\section{Results}

Water samples were collected from small streams or springs of watersheds that were mainly within National Forests or Bureau of Land Management lands. The watersheds are generally mountainous headwaters and are not impacted by historic mining. The ranges and means of species and other parameters were determined for each of the five rock groups. A summary of the mean geochemical data of waters collected within each of the groups is shown in Table 1. In addition, total dissolved solids (TDS) values were calculated for each site. The TDS value represents the total amount of solids $(\mathrm{mg} / \mathrm{L})$ remaining when a water sample is evaporated to dryness. In calculation from the chemical data, TDS value is the sum of all dissolved constituents with bicarbonate converted to equivalent carbonate in the solid phase, which assumes that half the bicarbonate is volatilized (Hem, 1992). The TDS value is calculated for the waters from each site and is shown in appendix 1.

\section{Minturn and Belden Formations in the Redcliff Area}

Water samples were collected from seven tributary streams of Turkey Creek and Eagle River in the Redcliff area in the White River National Forest (fig. 2). The watersheds are underlain by Pennsylvanian Minturn and Belden Formations of sandstone, grit, conglomerate, shale, and carbonate rocks (Tweto, 1979). The relief in the area is high and the dominant vegetation is subalpine forest (Kuchler, 1965). Annual precipitation ranges from 25 to 40 inches (Colorado Climate Center, 1984). The ranges and means of selected species in the waters are shown in Table 2. The sites contain $\mathrm{Ca}^{2+}-\mathrm{HCO}_{3}{ }^{-}$type waters with alkaline $\mathrm{pH}$ values. Mean $\mathrm{pH}$ is 8.33 and mean conductivity is $295 \mu \mathrm{S} / \mathrm{cm}$. Mean total dissolved solids (TDS) is higher than 
Table 1. Means of selected chemistry of waters from areas underlain by Permian and Pennsylvanian sedimentary rocks. Conductivity in $\mu \mathrm{S} / \mathrm{cm}$, alkalinity in $\mathrm{mg} / \mathrm{L} \mathrm{HCO}_{3}, \mathrm{TDS}, \mathrm{Ca}, \mathrm{Mg}, \mathrm{Na}, \mathrm{K}, \mathrm{Si}, \mathrm{SO} 4, \mathrm{Cl}, \mathrm{F}$, and $\mathrm{N}$ in $\mathrm{mg} / \mathrm{L}$, remaining elements in $\mu \mathrm{g} / \mathrm{L}$.

\begin{tabular}{|c|c|c|}
\hline Variable & $\begin{array}{c}\text { Minturn and Belden Fms } \\
\text { in the Redcliff Area } \\
\end{array}$ & $\begin{array}{c}\text { Minturn and Belden Fms } \\
\text { in the Flat Tops Area }\end{array}$ \\
\hline $\mathrm{n}$ & 7 & 8 \\
\hline $\mathrm{pH}$ & 8.33 & 7.82 \\
\hline Conductivity & 295 & 392 \\
\hline TDS & 240 & 312 \\
\hline $\mathrm{Ca}$ & 41 & 74 \\
\hline $\mathrm{Mg}$ & 11 & 3.1 \\
\hline $\mathrm{Na}$ & 1.6 & 1.3 \\
\hline $\mathrm{K}$ & 0.5 & $<0.5$ \\
\hline Alkalinity & 325 & 402 \\
\hline $\mathrm{SO}_{4}$ & 13 & 5.4 \\
\hline $\mathrm{Cl}$ & $<1$ & $<1$ \\
\hline $\mathrm{F}$ & $<0.05$ & $<0.05$ \\
\hline $\mathrm{N}$ & $<0.05$ & 0.22 \\
\hline $\mathrm{Li}$ & 2.5 & 0.6 \\
\hline $\mathrm{Ba}$ & 82 & 45 \\
\hline $\mathrm{Sr}$ & 102 & 127 \\
\hline $\mathrm{Al}$ & 3.6 & 1.6 \\
\hline $\mathrm{Fe}$ & 1.3 & 2.1 \\
\hline $\mathrm{Mn}$ & 0.36 & 1 \\
\hline $\mathrm{Cu}$ & $<0.5$ & $<0.5$ \\
\hline $\mathrm{Zn}$ & $<0.5$ & $<0.5$ \\
\hline Mo & 0.5 & 0 \\
\hline $\mathrm{Cr}$ & $<1$ & 3 \\
\hline $\mathrm{Ni}$ & 1.2 & 1.9 \\
\hline U & 1.4 & 0.8 \\
\hline
\end{tabular}


Table 1 cont. Means of selected chemistry of waters from areas underlain by Permian and Pennsylvanian sedimentary rocks. Conductivity in $\mu \mathrm{S} / \mathrm{cm}$, alkalinity in $\mathrm{mg} / \mathrm{L}$ $\mathrm{HCO}_{3}$, TDS, Ca, Mg, Na, K, Si, SO4, Cl, F, and $\mathrm{N}$ in mg/L, remaining elements in $\mu \mathrm{g} / \mathrm{L}$.

Variable Minturn and Belden Fms in Evaporite Facies of Eagle Sangre De Cristo Formation the Sangre de Cristo Area Valley and South Park

\begin{tabular}{|c|c|c|c|}
\hline $\mathrm{n}$ & 6 & 11 & 11 \\
\hline $\mathrm{pH}$ & 8.15 & 8.09 & 7.86 \\
\hline Conductivity & 429 & 685 & 172 \\
\hline TDS & 334 & 528 & 137 \\
\hline $\mathrm{Ca}$ & 57 & 103 & 24 \\
\hline $\mathrm{Mg}$ & 19 & 21 & 4 \\
\hline $\mathrm{Na}$ & 3.2 & 7.8 & 1.9 \\
\hline $\mathrm{K}$ & 1.3 & 1.2 & $<0.5$ \\
\hline Alkalinity & 322 & 369 & 179 \\
\hline $\mathrm{SO}_{4}$ & 64 & 155 & 6.6 \\
\hline $\mathrm{Cl}$ & $<1$ & 3.6 & $<1$ \\
\hline $\mathrm{F}$ & 0.09 & 0.08 & $<0.05$ \\
\hline $\mathrm{N}$ & $<0.05$ & $<0.05$ & $<0.05$ \\
\hline $\mathrm{Li}$ & 1.9 & 4.0 & 1.1 \\
\hline $\mathrm{Ba}$ & 42 & 56 & 66 \\
\hline $\mathrm{Sr}$ & 472 & 1071 & 121 \\
\hline $\mathrm{Al}$ & 2.3 & 2.7 & 1.6 \\
\hline $\mathrm{Fe}$ & 2.4 & 10 & 1.8 \\
\hline $\mathrm{Mn}$ & 0.58 & 4.1 & 0.23 \\
\hline $\mathrm{Cu}$ & 0.5 & 1 & $<0.5$ \\
\hline $\mathrm{Zn}$ & 1.1 & 1.7 & $<0.5$ \\
\hline Mo & 1.8 & 1.8 & 0.3 \\
\hline $\mathrm{Cr}$ & 1 & 1 & 1.1 \\
\hline $\mathrm{Ni}$ & 1.7 & 3.2 & 0.7 \\
\hline $\mathrm{U}$ & 1.3 & 1.5 & 0.35 \\
\hline
\end{tabular}




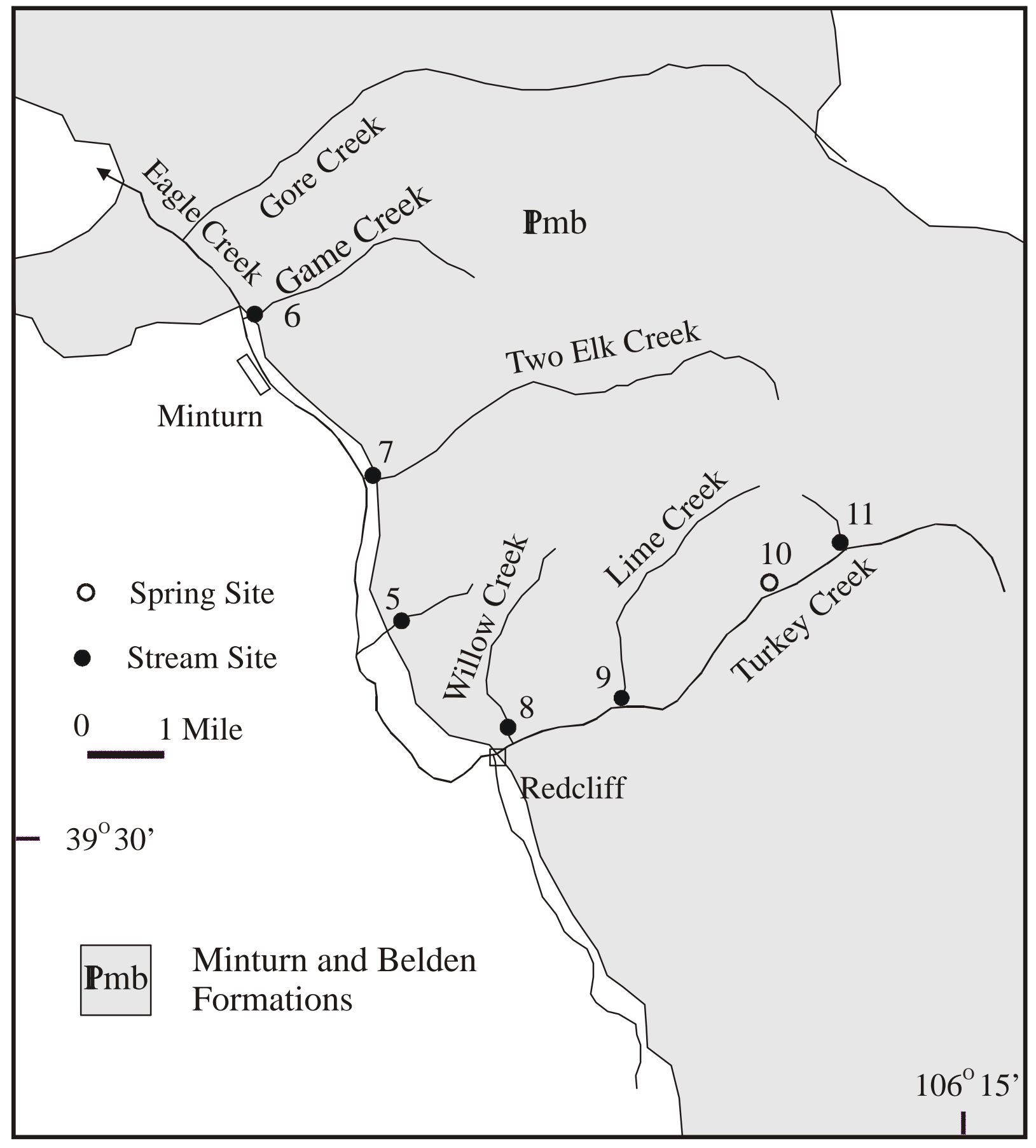

Figure 2. Locations of water samples from stream and spring sites in the Redcliff area. Geology generalized from Tweto (1979). 
Table 2. Summary of selected water chemistry of six streams and one spring in watersheds underlain by Pennsylvanian Minturn and Belden Formations in the Redcliff area $(\mathrm{n}=7)$. Conductivity in $\mu \mathrm{S} / \mathrm{cm}$, alkalinity as $\mathrm{mg} / \mathrm{L} \mathrm{HCO}_{3}$, TDS, $\mathrm{Ca}, \mathrm{Mg}, \mathrm{Na}, \mathrm{K}, \mathrm{Si}, \mathrm{SO}_{4}, \mathrm{Cl}, \mathrm{F}$, and $\mathrm{N}$ in $\mathrm{mg} / \mathrm{L}$, remaining elements in $\mu \mathrm{g} / \mathrm{L}$. Values below level of detection were replaced with values of 0.7 the level of detection.

\begin{tabular}{|c|c|c|c|}
\hline \multirow[t]{2}{*}{ Measurement } & \multicolumn{2}{|c|}{ Range } & \multirow[t]{2}{*}{ Mean } \\
\hline & Minimum & Maximum & \\
\hline Conductivity & 187 & 564 & 295 \\
\hline TDS & 159 & 426 & 240 \\
\hline $\mathrm{pH}$ & 7.47 & 8.57 & 8.33 \\
\hline $\mathrm{Ca}$ & 29 & 86 & 41 \\
\hline $\mathrm{Mg}$ & 2.5 & 19 & 11 \\
\hline $\mathrm{Na}$ & 1.3 & 2.3 & 1.6 \\
\hline $\mathrm{K}$ & 0.3 & 1.1 & 0.5 \\
\hline $\mathrm{Si}$ & 2.9 & 4.7 & 3.3 \\
\hline Alkalinity & 239 & 393 & 325 \\
\hline $\mathrm{SO}_{4}$ & 2.5 & 119 & 13 \\
\hline $\mathrm{Cl}$ & $<1$ & $<1$ & $<1$ \\
\hline $\mathrm{F}$ & $<0.05$ & 0.05 & $<0.05$ \\
\hline $\mathrm{N}$ & $<0.05$ & 0.08 & $<0.05$ \\
\hline $\mathrm{Al}$ & 2.1 & 7.4 & 3.6 \\
\hline $\mathrm{Fe}$ & 1 & 2 & 1 \\
\hline Mn & 0.1 & 4.2 & 0.4 \\
\hline $\mathrm{Cu}$ & $<0.5$ & 0.6 & $<0.5$ \\
\hline $\mathrm{Zn}$ & $<0.5$ & 0.7 & $<0.5$ \\
\hline Mo & 0.3 & 1.3 & 0.5 \\
\hline $\mathrm{Cr}$ & $<1$ & 1 & $<1$ \\
\hline $\mathrm{Ni}$ & 0.8 & 2.1 & 1.2 \\
\hline $\mathrm{U}$ & 1 & 2.1 & 1.4 \\
\hline $\mathrm{Li}$ & 1.3 & 4.1 & 2.5 \\
\hline $\mathrm{Ba}$ & 62 & 167 & 82 \\
\hline $\mathrm{Sr}$ & 53 & 597 & 102 \\
\hline
\end{tabular}


average river water (Table 3) with a mean of $240 \mathrm{mg} / \mathrm{L}$. The mean concentrations of $\mathrm{Fe}, \mathrm{Al}$, and $\mathrm{Mn}$ are low compared to average river water with values of 1, 0.4, and $3.6 \mathrm{mg} / \mathrm{L}$, respectively. Other trace metals are also low. Mean concentrations of $\mathrm{Zn}, \mathrm{Cu}, \mathrm{Mo}$, and $\mathrm{U}$ are $<0.5,<0.5,0.5$, and 1.4. Si concentrations are low with a mean of $3.3 \mathrm{mg} / \mathrm{L}$ probably because of the rock type which contains abundant carbonate minerals as well a gypsum. Alkalinity values are high with a mean of $325 \mathrm{mg} / \mathrm{L}$, probably because of the carbonate rocks within the formations. $\mathrm{Mean} \mathrm{Cl}$ content is $<1 \mathrm{mg} / \mathrm{L}$, which is low and reflects the short residence time of the melting snow and storm runoff in contact with the rocks and lack of significant evaporation. Because of the high alkalinity values, the areas underlain by rocks of the Minturn and Belden Formations in the Redcliff area are moderately resistant to introduced acidification, such as a coal-burning power plant or acidity from mining wastes. The chemical quality of the waters from watersheds underlain by Pennsylvanian Minturn and Belden Formations in this area is good.

\section{Minturn and Belden Formations in the Flat Tops Area}

Samples of water were collected from three streams and five springs in the Flat Tops area in the White River National Forest (fig. 3). The watersheds are underlain by Pennsylvanian Belden and Minturn Formations of sandstone, grit, conglomerate, shale, and carbonate rocks (Tweto, 1979). Relief is high along the flanks but the upland area containing the springs is generally flat lying. The dominant vegetation is subalpine forests with alpine meadows in the upland area (Kuchler, 1965). Annual precipitation ranges from 20 to 40 inches (Colorado Climate Center, 1984). The ranges and means of selected species in the waters are shown in Table 4. The sites contain $\mathrm{Ca}^{2+}-\mathrm{HCO}_{3}{ }^{-}$type waters with alkaline $\mathrm{pH}$ values. Mean $\mathrm{pH}$ is 7.82 and mean conductivity is $392 \mu \mathrm{S} / \mathrm{cm}$. Mean TDS value is higher than average river water (Table 3) with a mean of $312 \mathrm{mg} / \mathrm{L}$. Mean concentrations of Al, Fe, and Mn are low with means of 1.6, 2, and $1 \mu \mathrm{g} / \mathrm{l}$, respectively. Other trace metals are also low. Mean $\mathrm{Zn}, \mathrm{Cu}, \mathrm{Mo}$, and $\mathrm{U}$ are $<0.5$, $<0.5,0.4$, and $0.8 \mu \mathrm{g} / \mathrm{l}$, respectively. Mean Si concentration is low with a mean of $4.3 \mathrm{mg} / \mathrm{L}$ probably because of the rock type which contains abundant carbonate minerals as well a gypsum. The mean $\mathrm{Cl}$ concentration is $<1 \mathrm{mg} / \mathrm{L}$, which is low and reflects the short residence time of the 
Table 3. Background of trace metals in freshwater and chemical analyses of mean river water

\begin{tabular}{cc}
\hline & Background of trace metals $(\mu \mathrm{g} / \mathrm{L})$ in freshwater \\
\hline \hline Element & Data after Forstner and Wittmann $(1979)$ \\
$\mathrm{Al}$ & $<30$ \\
$\mathrm{Fe}$ & $<30$ \\
$\mathrm{Mn}$ & $<5$ \\
$\mathrm{Cu}$ & 1.8 \\
$\mathrm{Zn}$ & 10 \\
$\mathrm{As}$ & 2 \\
$\mathrm{Mo}$ & 1 \\
$\mathrm{~Pb}$ & 0.2 \\
$\mathrm{Sb}$ & 0.1 \\
$\mathrm{Cr}$ & 0.5 \\
$\mathrm{Ni}$ & 0.3 \\
$\mathrm{Li}$ & 1 \\
$\mathrm{Se}$ & 0.1 \\
$\mathrm{U}$ & 0.5 \\
\hline
\end{tabular}

Chemical analyses (in $\mathrm{mg} / \mathrm{L}$ ) of mean river water

Element in $\mathrm{mg} / \mathrm{L}$

Data from Livingstone (1963)

$\begin{array}{cc}\mathrm{Ca} & 15 \\ \mathrm{Mg} & 4.1 \\ \mathrm{Na} & 6.3 \\ \mathrm{~K} & 2.3 \\ \mathrm{Si} & 6.1 \\ \mathrm{SO}_{4} & 11.2 \\ \mathrm{HCO}_{3} & 58.4 \\ \mathrm{Cl} & 7.8\end{array}$




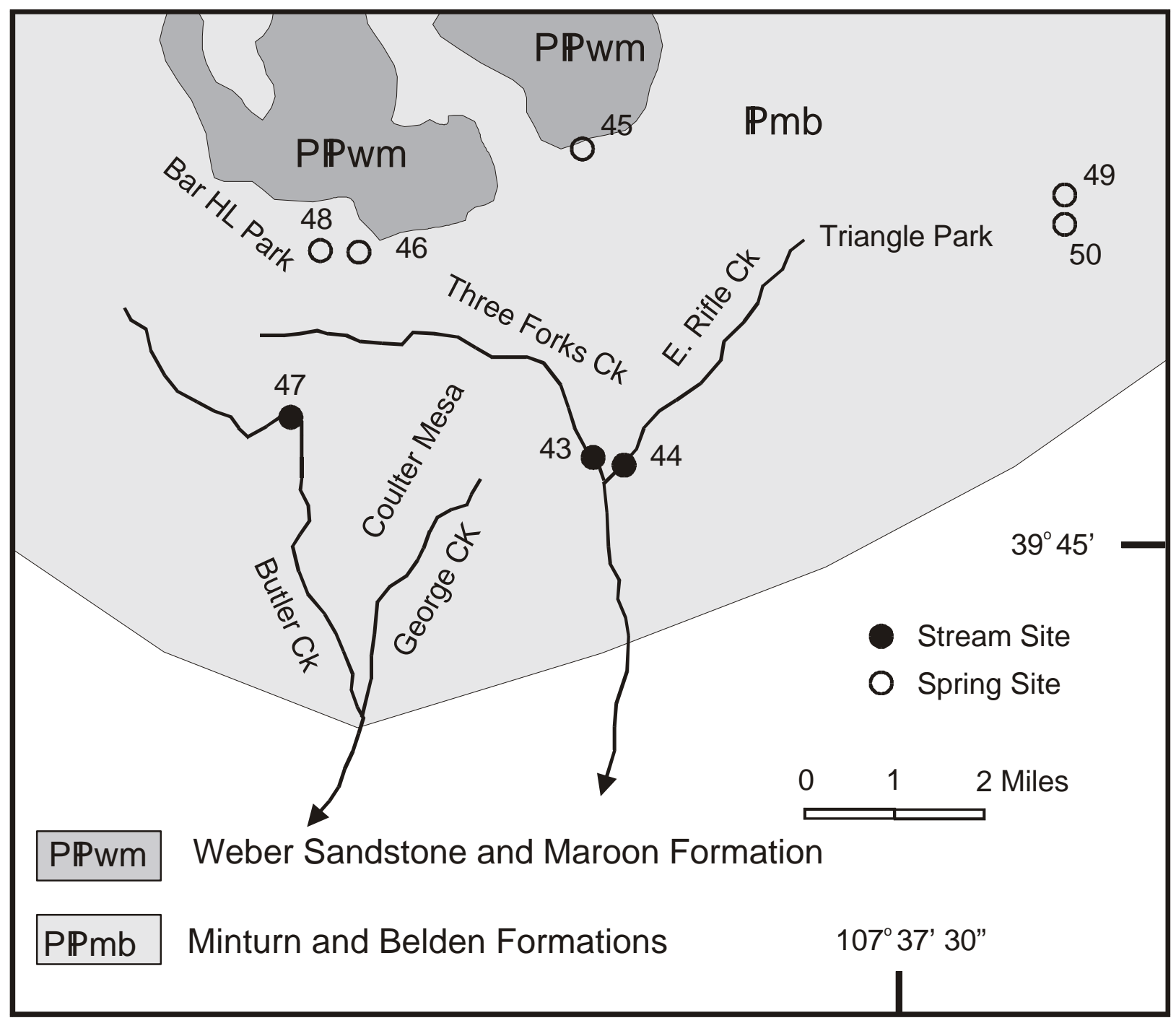

Figure 3. Locations of water samples from streams and springs in the Flat Tops area. Geology generalized from Tweto (1979). 
Table 4. Summary of selected water chemistry of three streams and five springs in watersheds underlain by Pennsylvanian Minturn and Belden Formations in the Flat Tops Area. $(\mathrm{n}=8)$. Conductivity in $\mu \mathrm{S} / \mathrm{cm}$, alkalinity as $\mathrm{mg} / \mathrm{L}$ $\mathrm{HCO}_{3}, \mathrm{TDS}, \mathrm{Ca}, \mathrm{Mg}, \mathrm{Na}, \mathrm{K}, \mathrm{Si}, \mathrm{SO}_{4}, \mathrm{Cl}, \mathrm{F}$, and $\mathrm{N}$ in $\mathrm{mg} / \mathrm{L}$, remaining elements in $\mu \mathrm{g} / \mathrm{L}$ Values below level of detection were replaced with values of 0.7 the level of detection.

\begin{tabular}{|c|c|c|c|}
\hline \multirow[t]{2}{*}{ Measurement } & \multicolumn{2}{|c|}{ Range } & \multirow[t]{2}{*}{ Mean } \\
\hline & Minimum & Maximum & \\
\hline Conductivity & 296 & 633 & 392 \\
\hline TDS & 228 & 479 & 312 \\
\hline $\mathrm{pH}$ & 7.46 & 8.31 & 7.82 \\
\hline $\mathrm{Ca}$ & 58 & 108 & 74 \\
\hline $\mathrm{Mg}$ & 1.1 & 18 & 3.1 \\
\hline $\mathrm{Na}$ & 1 & 2.3 & 1.3 \\
\hline $\mathrm{K}$ & $<0.5$ & 0.55 & $<0.5$ \\
\hline $\mathrm{Si}$ & 3.7 & 5 & 4.3 \\
\hline Alkalinity & 326 & 465 & 402 \\
\hline $\mathrm{SO}_{4}$ & 1.4 & 143 & 5.4 \\
\hline $\mathrm{Cl}$ & $<1$ & 1.1 & $<1$ \\
\hline $\mathrm{F}$ & $<0.05$ & 0.1 & $<0.05$ \\
\hline $\mathrm{N}$ & $<0.05$ & 0.87 & 0.22 \\
\hline $\mathrm{Al}$ & 0.9 & 2.2 & 1.6 \\
\hline $\mathrm{Fe}$ & 1 & 14 & 2 \\
\hline $\mathrm{Mn}$ & 0.02 & 13 & 1 \\
\hline $\mathrm{Cu}$ & $<0.5$ & 0.6 & $<0.5$ \\
\hline $\mathrm{Zn}$ & $<0.5$ & 0.6 & $<0.5$ \\
\hline Mo & $<0.2$ & 2.2 & 0.4 \\
\hline $\mathrm{Cr}$ & 2.1 & 2.8 & 2.5 \\
\hline $\mathrm{Ni}$ & 1.4 & 2.9 & 1.9 \\
\hline $\mathrm{U}$ & 0.4 & 2.4 & 0.8 \\
\hline $\mathrm{Li}$ & 0.3 & 2.9 & 0.6 \\
\hline $\mathrm{Ba}$ & 34 & 60 & 45 \\
\hline $\mathrm{Sr}$ & 53 & 1040 & 127 \\
\hline
\end{tabular}


water from melting snow and rain in contact with the rocks and the lack of significant evaporation. Alkalinity values are high with a mean $402 \mathrm{mg} / \mathrm{L}$, which indicates good acidneutralizing capacity probably because of abundant carbonate minerals in the rocks. Because of the high alkalinity values, the areas underlain by rocks of the Minturn and Belden Formations are moderately resistant to introduced acidification. The chemical quality of the waters from watersheds underlain by Pennsylvanian Minturn and Belden Formations in this area is good.

\section{Minturn and Belden Formations in the Sangre de Cristo Range}

Samples of water were collected form six streams in the northern Sangre de Cristo Range within the San Isabel and Rio Grande National Forest (figs. 4 and 5). The watersheds are underlain by Pennsylvanian Minturn and Belden Formations of shale, siltstone, and sandstone with beds of gypsum and marine limestone (Tweto, 1979). Relief is high and the dominant vegetation is pine-Douglas fir and spruce-fir forest in the higher areas and juniper-pinyon woodland along the lower flanks (Kuchler, 1965). Annual precipitation ranges from 16 to 40 inches (Colorado Climate Center, 1984). The ranges and means of selected species in the waters

are shown in Table 5. The sites contain $\mathrm{Ca}^{2+}-\mathrm{HCO}_{3}{ }^{-}$type waters with alkaline $\mathrm{pH}$ values. Mean $\mathrm{pH}$ is 8.15 and mean conductivity is $429 \mu \mathrm{S} / \mathrm{cm}$. Mean TDS value is higher than average river water (Table 3) with a mean of $334 \mathrm{mg} / \mathrm{L}$. The mean concentrations of $\mathrm{Al}, \mathrm{Fe}$, and $\mathrm{Mn}$ are low with means of $2.3,2$, and $0.6 \mu \mathrm{g} / 1$, respectively. Other trace metal concentrations are low. Mean concentrations of $\mathrm{Zn}, \mathrm{Cu}, \mathrm{Mo}$, and $\mathrm{U}$ are $1.1,0.5$, 1.8, and $1.3 \mu \mathrm{g} / \mathrm{l}$, respectively. Mean Si concentration is $5.2 \mathrm{mg} / \mathrm{L}$ probably because of the rock type which contains abundant carbonate minerals as well a gypsum. Mean $\mathrm{Cl}$ concentration is $<1 \mathrm{mg} / \mathrm{L}$, which is low and reflects the short residence time of the water from melting snow and rain in contact with the rocks and the lack of significant evaporation. Mean alkalinity as $\mathrm{HCO}_{3}{ }^{-}$is $322 \mathrm{mg} / \mathrm{L}$, which indicates good acid-neutralizing capacity probably because of abundant carbonate minerals in the rocks. Because of the high alkalinity values, the areas underlain by rocks of the Minturn and Belden Formations are moderately resistant to introduced acidification. The chemical quality of the waters from watersheds underlain by Pennsylvanian Minturn and Belden Formations is good. 


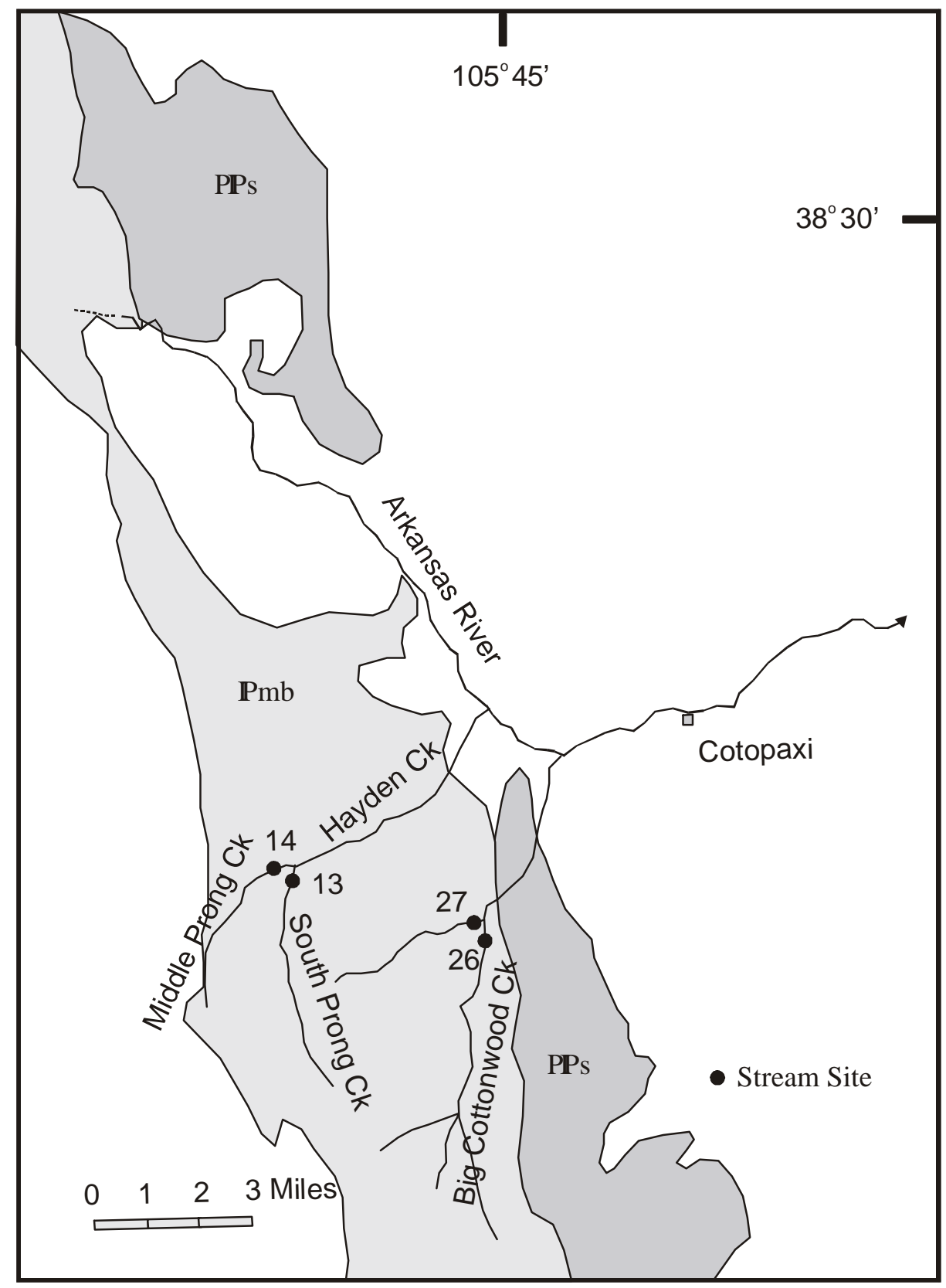

PPs Sangre de Cristo Formation

Pmb Minturn and Belden Formation

Figure 4. Locatins of waters from stream sites in the northern Sangre de Cristo Range. Geology generalized from Tweto (1979). 


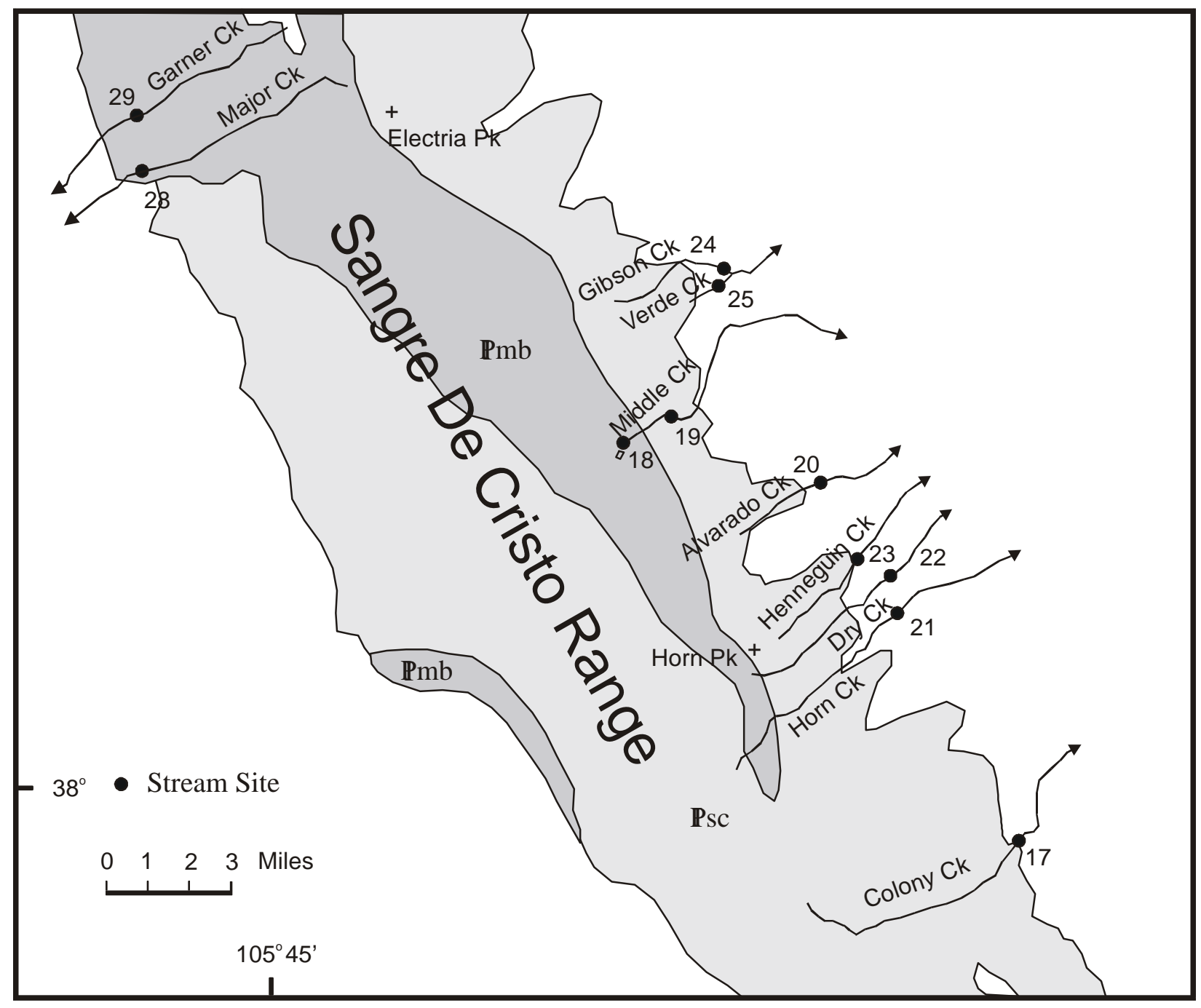

Psc Sangre de Cristo Formation

Pmb Minturn and Belden Formatins

Figure 5. Locations of water samples from streams from the Sangre de Cristo Range. Geology generalized from Tweto (1979). 
Table 5. Summary of selected water chemistry of six streams in watersheds underlain by Pennsylvanian Minturn and Belden Formations in the Sangre de Cristo Range ( $\mathrm{n}=6)$. Conductivity in $\mu \mathrm{S} / \mathrm{cm}$, alkalinity $\mathrm{mg} / \mathrm{L} \mathrm{HCO}_{3}$, TDS, Ca, $\mathrm{Mg}, \mathrm{Na}, \mathrm{K}, \mathrm{Si}, \mathrm{SO}_{4}, \mathrm{Cl}, \mathrm{F}$, and $\mathrm{N}$ in $\mathrm{mg} / \mathrm{L}$, remaining elements in $\mu \mathrm{g} / \mathrm{L}$. Values below level of detection were replaced with values of 0.7 the level of detection

\begin{tabular}{|c|c|c|c|}
\hline \multirow[t]{2}{*}{ Measurement } & \multicolumn{2}{|c|}{ Range } & \multirow[t]{2}{*}{ Mean } \\
\hline & Minimum & Maximum & \\
\hline Conductivity & 235 & 632 & 429 \\
\hline TDS & 197 & 469 & 334 \\
\hline $\mathrm{pH}$ & 7.11 & 8.56 & 8.15 \\
\hline $\mathrm{Ca}$ & 31 & 91 & 57 \\
\hline $\mathrm{Mg}$ & 11 & 30 & 19 \\
\hline $\mathrm{Na}$ & 1.3 & 4.7 & 3.2 \\
\hline $\mathrm{K}$ & 0.64 & 3.2 & 1.3 \\
\hline $\mathrm{Si}$ & 3.1 & 7 & 5.2 \\
\hline Alkalinity & 285 & 444 & 322 \\
\hline $\mathrm{SO}_{4}$ & 6.2 & 169 & 64 \\
\hline $\mathrm{Cl}$ & $<1$ & 1.3 & $<1$ \\
\hline $\mathrm{F}$ & $<0.05$ & 0.15 & 0.09 \\
\hline $\mathrm{N}$ & $<0.05$ & 0.07 & $<0.05$ \\
\hline $\mathrm{Al}$ & 0.88 & 6.3 & 2.3 \\
\hline $\mathrm{Fe}$ & 1 & 5 & 2 \\
\hline $\mathrm{Mn}$ & 0.3 & 7.6 & 0.6 \\
\hline $\mathrm{Cu}$ & $<0.5$ & 0.9 & 0.5 \\
\hline $\mathrm{Zn}$ & 0.5 & 19 & 1.1 \\
\hline Mo & 0.53 & 8.1 & 1.8 \\
\hline $\mathrm{Cr}$ & $<1$ & 3.2 & 1 \\
\hline $\mathrm{Ni}$ & 0.9 & 2.6 & 1.7 \\
\hline $\mathrm{U}$ & 1 & 1.8 & 1.3 \\
\hline $\mathrm{Li}$ & 0.5 & 4.5 & 1.9 \\
\hline $\mathrm{Ba}$ & 38 & 47 & 42 \\
\hline $\mathrm{Sr}$ & 120 & 1310 & 472 \\
\hline
\end{tabular}




\section{Evaporitic Facies in the Eagle Valley and South Park Areas}

Samples of water draining Evaporite Facies rocks were collected form five streams and three springs in the Eagle Valley and two streams and one well in the South Park area (figs. 6, 7 and 8). Because the water samples were from areas underlain with rocks containing evaporite minerals, particularly gypsum, the samples from the two areas were lumped together. The watersheds in the Eagle Valley are underlain by Pennsylvanian Eagle Valley Evaporite of gypsum, anhydrite and interbedded siltstone and minor dolomite and Pennsylvanian Eagle Valley Formation of siltstone, shale, sandstone, carbonate, and lenses of gypsum (Tweto, 1979). The watersheds of the South Park area are underlain by the evaporite facies member of the Pennsylvanian Minturn and Belden Formations (Tweto, 1979). Relief varies from high in the Eagle Valley and moderate to low in the South Park area. The dominant vegetation is western spruce-fir forest in the higher areas and juniper-pinyon scrub and sagebrush along the flanks and Eagle Valley and alpine meadow and grasslands in South Park (Kuchler, 1965). Annual precipitation ranges from 12 to 30 inches in the Eagle Valley and 12 to 25 inches in South Park (Colorado Climate Center, 1984). The ranges and means of selected species in the waters are shown in Table 6. The sites contain nine $\mathrm{Ca}^{2+}-\mathrm{HCO}_{3}{ }^{-}$and two $\mathrm{Ca}^{2+}-\mathrm{SO}_{4}{ }^{2-}$ type waters with alkaline $\mathrm{pH}$ values. Mean $\mathrm{pH}$ is 8.09 and mean conductivity is $685 \mu \mathrm{S} / \mathrm{cm}$. Mean TDS value is higher than average river water (Table 3 ) with a mean of $334 \mathrm{mg} / \mathrm{L}$. Trace metal concentrations are low. Mean concentrations of $\mathrm{Al}, \mathrm{Fe}$, and $\mathrm{Mn}$ are moderately low with means of 2.7, 10, and $4.1 \mu \mathrm{g} / \mathrm{l}$, respectively. Other trace metal concentrations are low. Mean $\mathrm{Zn}, \mathrm{Cu}, \mathrm{Mo}$, and $\mathrm{U}$ are 1.7, 1, 1.8, and $1.5 \mu \mathrm{g} / \mathrm{l}$, respectively. Mean Si concentration $7.5 \mathrm{mg} / \mathrm{L}$. Mean Cl concentration is $3.6 \mathrm{mg} / \mathrm{L}$, which is slightly higher than the waters from the other rock composition types probably because of the presence of minor halite in the Evaporite Facies rocks. Mean alkalinity is $369 \mathrm{mg} / \mathrm{L}$, which indicates good acid-neutralizing capacity probably because of abundant carbonate minerals in the rocks. Because of the high alkalinity values, the areas underlain by rocks containing evaporite minerals are moderately resistant to introduced acidification. The 


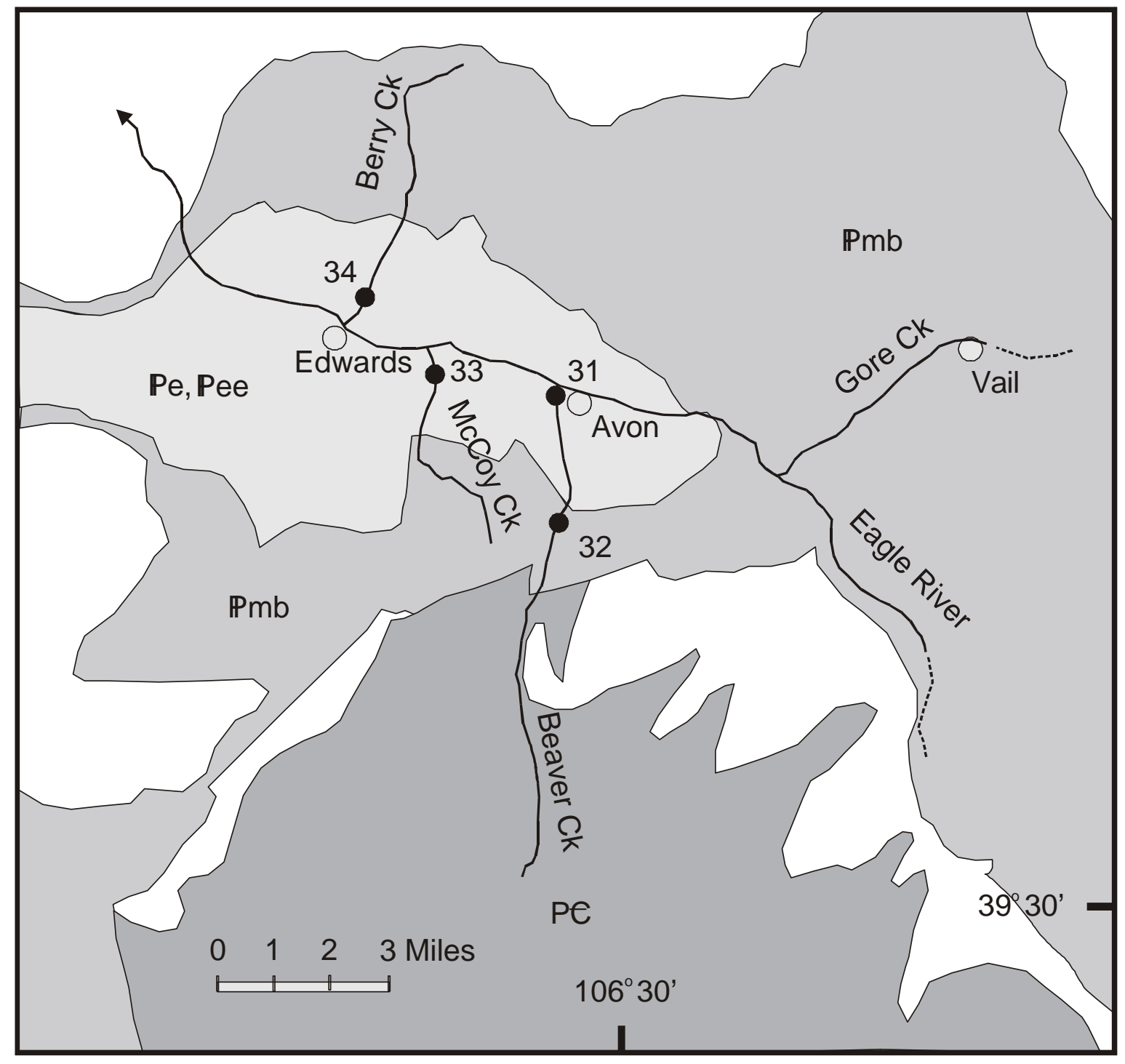

Pe, Pee Eagle Valley Formation and Evaporitic Facies

$\mathbb{P m b}$ Minturn and Belden Formations - Stream Site

PC Precambrian Rocks

Figure 6. Locations of water samples from steams in the Upper Eagle River Valley. Geology is generalized from Tweto (1979). 


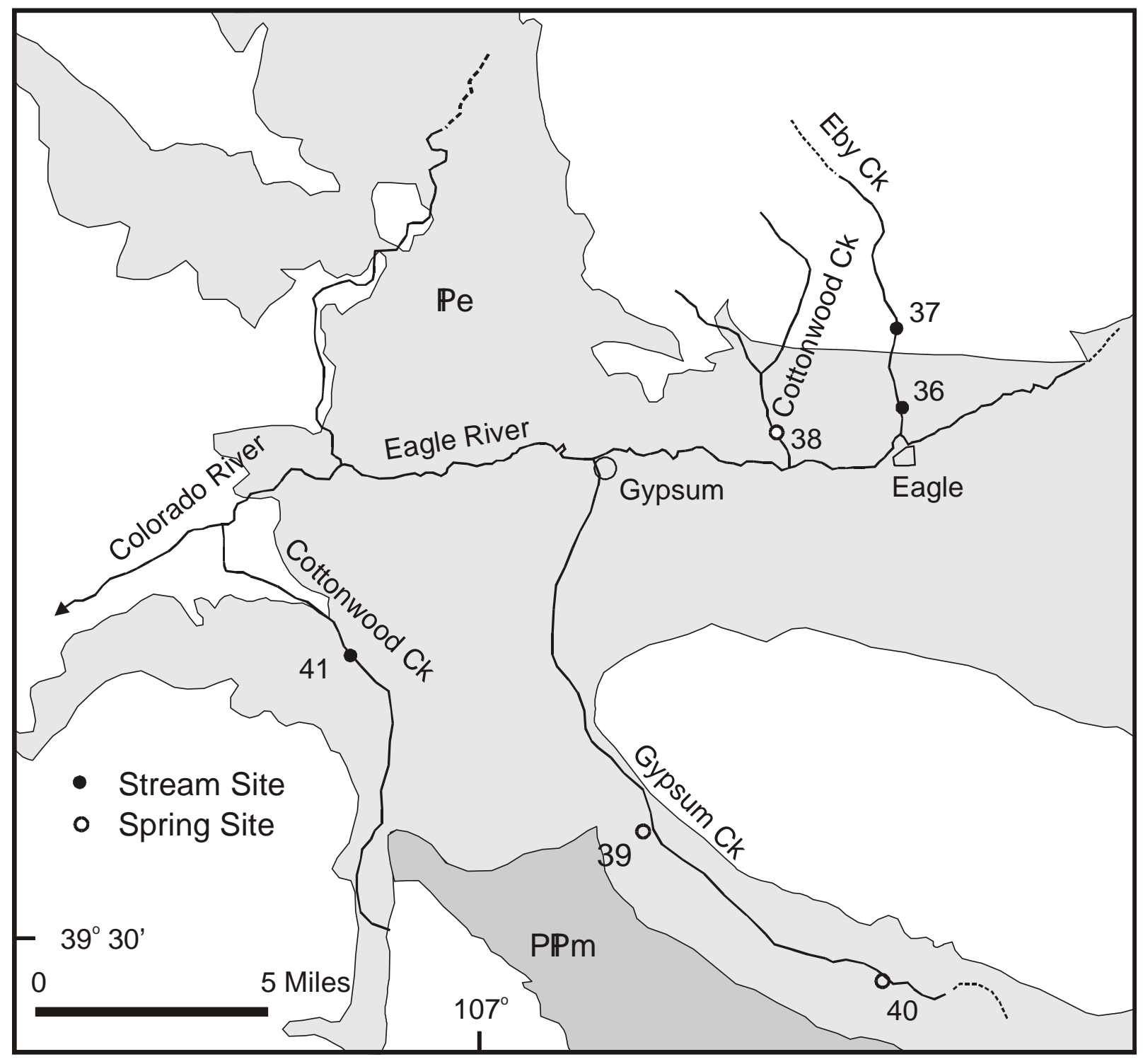

PPm Maroon Formation

$\mathbb{P e} \quad$ Evaporitic Facies

Figure 7. Locations of water samples from stream and spring sites in the lower Eagle River Valley. Geology generalized from Tweto (1979). 


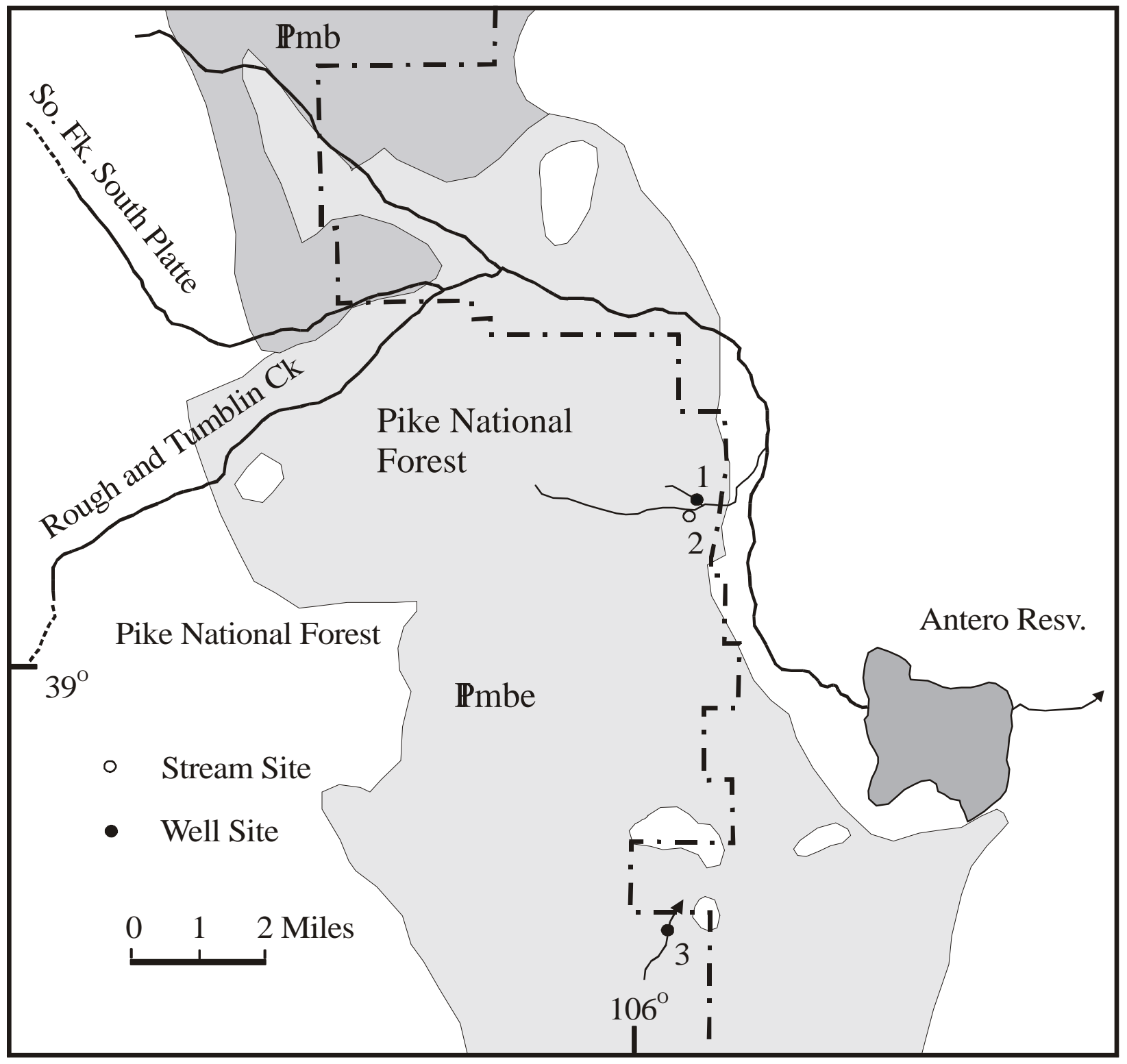

\begin{tabular}{|l} 
Evaporitic Facies of Minturn and \\
Belden Formations of South Park
\end{tabular}

Pmb Minturn and Belden Formations

Figure 8. Locations of water samples from stream and well sites in South South Park. Geology generalized from Tweto (1979). 
Table 6. Summary of selected water chemistry of eight streams, two springs and one well in watersheds underlain by Pennsylvanian Evaporite Facies rocks in Eagle Valley and South Park $(\mathrm{n}=11)$. Conductivity in $\mu \mathrm{S} / \mathrm{cm}$, alkalinity as $\mathrm{mg} / \mathrm{L}$ $\mathrm{HCO}_{3}, \mathrm{TDS}, \mathrm{Ca}, \mathrm{Mg}, \mathrm{Na}, \mathrm{K}, \mathrm{Si}, \mathrm{SO}_{4}, \mathrm{Cl}, \mathrm{F}$, and $\mathrm{N}$ in $\mathrm{mg} / \mathrm{L}$, remaining elements in $\mu \mathrm{g} / \mathrm{L}$. Values below level of detection were replaced with values of 0.7 the level of detection

\begin{tabular}{|c|c|c|c|}
\hline \multirow[t]{2}{*}{ Measurement } & \multicolumn{2}{|c|}{ Range } & \multirow[t]{2}{*}{ Mean } \\
\hline & Minimum & Maximum & \\
\hline Conductivity & 232 & 2020 & 685 \\
\hline TDS & 169 & 1757 & 528 \\
\hline $\mathrm{pH}$ & 7.49 & 8.65 & 8.09 \\
\hline $\mathrm{Ca}$ & 30 & 387 & 103 \\
\hline $\mathrm{Mg}$ & 7 & 74 & 21 \\
\hline $\mathrm{Na}$ & 2.7 & 60 & 7.8 \\
\hline $\mathrm{K}$ & $<0.5$ & 5.6 & 1.2 \\
\hline $\mathrm{Si}$ & 3.8 & 14 & 7.5 \\
\hline Alkalinity & 177 & 575 & 369 \\
\hline $\mathrm{SO}_{4}$ & 19 & 972 & 155 \\
\hline $\mathrm{Cl}$ & $<1$ & 24 & 3.6 \\
\hline $\mathrm{F}$ & $<0.05$ & 0.89 & 0.08 \\
\hline $\mathrm{N}$ & $<0.05$ & 0.07 & $<0.05$ \\
\hline $\mathrm{Al}$ & 0.88 & 8.2 & 2.7 \\
\hline $\mathrm{Fe}$ & 1 & 20 & 10 \\
\hline $\mathrm{Mn}$ & 0.06 & 441 & 4.1 \\
\hline $\mathrm{Cu}$ & $<0.5$ & 2.3 & 1 \\
\hline $\mathrm{Zn}$ & $<0.5$ & 123 & 1.7 \\
\hline Mo & 0.5 & 8.6 & 1.8 \\
\hline $\mathrm{Cr}$ & $<1$ & 3.8 & 1 \\
\hline $\mathrm{Ni}$ & 1.1 & 14.4 & 3.2 \\
\hline $\mathrm{U}$ & 0.37 & 6.1 & 1.5 \\
\hline $\mathrm{Li}$ & $<0.1$ & 110 & 4 \\
\hline $\mathrm{Ba}$ & 20 & 116 & 56 \\
\hline $\mathrm{Sr}$ & 215 & 4720 & 1071 \\
\hline
\end{tabular}


chemical quality of the waters from watersheds underlain by Evaporite Facies rocks is good except for moderately high total dissolved solids.

\section{Sangre de Cristo Formation in the Sangre de Cristo Range}

Water samples were collected from 11 streams in the Sangre de Cristo Range within the San Isabel and Rio Grande National Forest (figs. 5 and 9). The watersheds are underlain by Permian and Pennsylvanian Sangre de Cristo Formation of conglomerate, arkose, sandstone, siltstone, and minor shale and limestone (Johnson, 1969). Relief is high and the dominant vegetation is pine-Douglas fir and western spruce-fir forest in the higher areas and juniperpinyon woodland along the lower flanks (Kuchler, 1965). Annual precipitation ranges from 16 to 40 inches (Colorado Climate Center, 1984). The ranges and means of selected species in the waters are shown in Table 7. The sites contain $\mathrm{Ca}^{2+}-\mathrm{HCO}_{3}{ }^{-}$type waters with alkaline $\mathrm{pH}$ values. Mean $\mathrm{pH}$ is 7.86 and mean conductivity is $172 \mu \mathrm{S} / \mathrm{cm}$. Mean TDS value is higher than average river water (Table 3) with a mean of $137 \mathrm{mg} / \mathrm{L}$. Mean concentrations of $\mathrm{Al}, \mathrm{Fe}$, and $\mathrm{Mn}$ are low with means of $1.6,2$, and $0.23 \mu \mathrm{g} / \mathrm{l}$, respectively. Other trace metal concentrations are low. Mean concentrations of $\mathrm{Zn}, \mathrm{Cu}, \mathrm{Mo}$, and $\mathrm{U}$ are $<0.5,<0.5,0.26$, and $0.35 \mu \mathrm{g} / \mathrm{l}$, respectively. Mean Si concentration is $3.4 \mathrm{mg} / \mathrm{L}$. The low mean compared to average waters is probably due to the rock type which contains abundant course silicate grains which are less soluble than finer grain silicate minerals. Mean $\mathrm{Cl}$ concentration is $<1 \mathrm{mg} / \mathrm{L}$, which is low and reflects the short residence time of the water from melting snow and rain in contact with the rocks and the lack of significant evaporation. Mean alkalinity is $172 \mathrm{mg} / \mathrm{L}$, probably because of the presence of minor carbonate minerals in the rocks and indicates acid-neutralizing capacity. The chemical quality of the waters from watersheds underlain by Permian and Pennsylvanian Sangre de Cristo Formation is good.

\section{Comparison of Water Chemistry from each of the Five Rock Groups}

The chemistry of water evolving in watersheds depends on the chemical composition of 


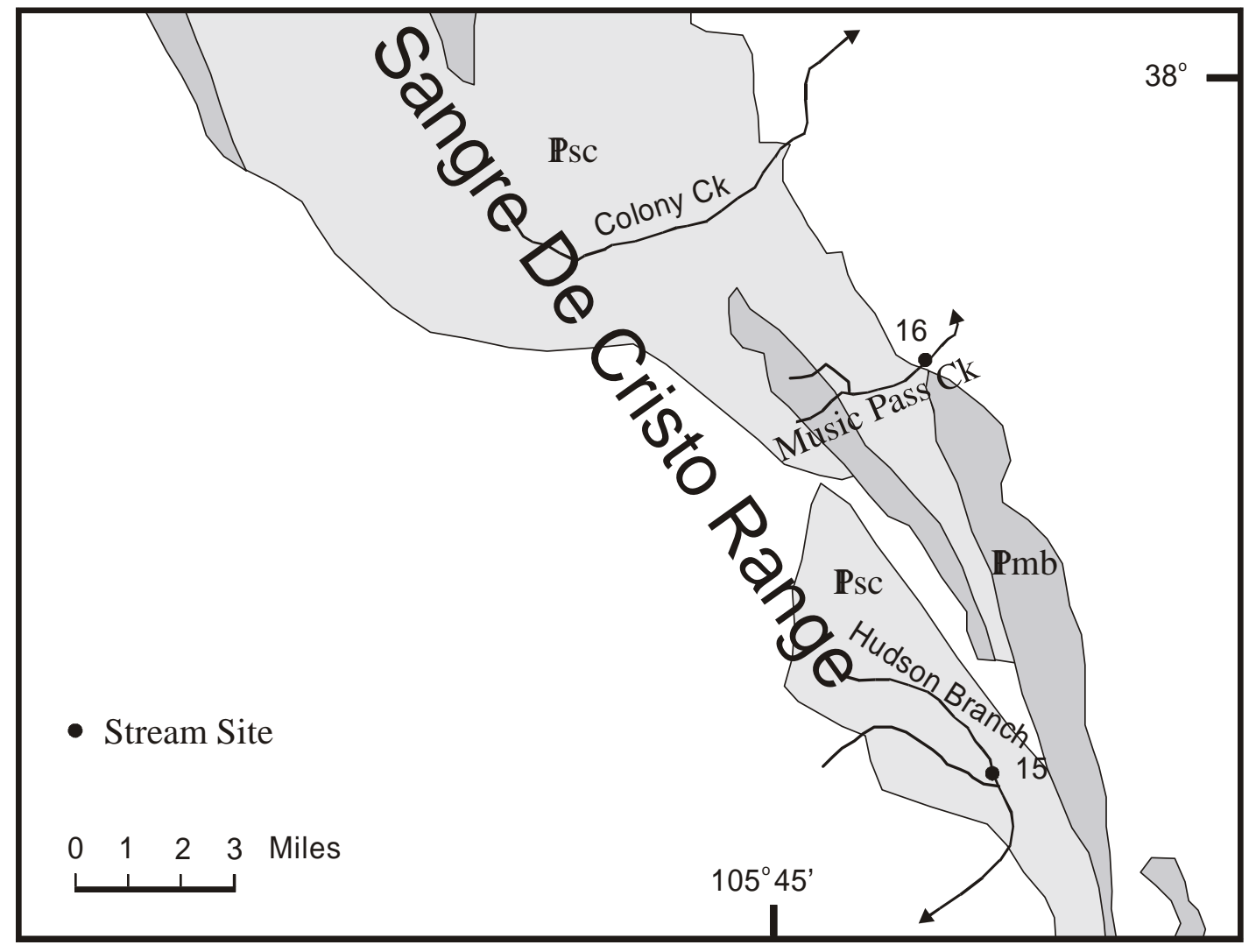

Psc Sangre de Cristo Formation

Pmb Minturn and Belden Formation

Figure 9. Locations of water samples from streams in the Sangre de Cristo Range. Geology is generalized from Tweto (1979). 
Table 7. Summary of selected water chemistry of 11 streams in watersheds underlain by Permian and Pennsylvanian Sangre de Cristo Formation in the Sangre de Cristo Range ( $\mathrm{n}=11)$. Conductivity in $\mu \mathrm{S} / \mathrm{cm}$, alkalinity as $\mathrm{mg} / \mathrm{L} \mathrm{HCO}_{3}, \mathrm{TDS}, \mathrm{Ca}, \mathrm{Mg}$, $\mathrm{Na}, \mathrm{K}, \mathrm{Si}, \mathrm{SO}_{4}, \mathrm{Cl}, \mathrm{F}$, and $\mathrm{N}$ in $\mathrm{mg} / \mathrm{L}$, remaining elements in $\mu \mathrm{g} / \mathrm{L}$. Values below level of detection were replaced with values of 0.7 the level of detection.

\begin{tabular}{|c|c|c|c|}
\hline \multirow[t]{2}{*}{ Measurement } & \multicolumn{2}{|c|}{ Range } & \multirow[t]{2}{*}{ Mean } \\
\hline & Minimum & Maximum & \\
\hline Conductivity & 63 & 294 & 172 \\
\hline TDS & 58 & 246 & 137 \\
\hline $\mathrm{pH}$ & 7.13 & 8.99 & 7.86 \\
\hline $\mathrm{Ca}$ & 6.9 & 39 & 24 \\
\hline $\mathrm{Mg}$ & 1.9 & 11 & 4.1 \\
\hline $\mathrm{Na}$ & 1 & 5.7 & 1.9 \\
\hline $\mathrm{K}$ & $<0.5$ & 0.57 & $<0.5$ \\
\hline $\mathrm{Si}$ & 1.5 & 6.6 & 3.4 \\
\hline Alkalinity & 81 & 359 & 179 \\
\hline $\mathrm{SO}_{4}$ & 1.8 & 55 & 6.6 \\
\hline $\mathrm{Cl}$ & $<1$ & $<1$ & $<1$ \\
\hline $\mathrm{F}$ & $<0.05$ & 0.14 & $<0.05$ \\
\hline $\mathrm{N}$ & $<0.05$ & $<0.05$ & $<0.05$ \\
\hline $\mathrm{Al}$ & 0.22 & 11 & 1.6 \\
\hline $\mathrm{Fe}$ & $<1$ & 16 & 2 \\
\hline $\mathrm{Mn}$ & $<0.01$ & 4.4 & 0.23 \\
\hline $\mathrm{Cu}$ & $<0.5$ & 0.6 & $<0.5$ \\
\hline $\mathrm{Zn}$ & $<0.5$ & 1 & $<0.5$ \\
\hline Mo & $<0.2$ & 1.4 & 0.26 \\
\hline $\mathrm{Cr}$ & $<1$ & 14 & 1.1 \\
\hline $\mathrm{Ni}$ & 0.3 & 1.2 & 0.7 \\
\hline $\mathrm{U}$ & 0.03 & 1.9 & 0.35 \\
\hline $\mathrm{Li}$ & 0.6 & 304 & 1.1 \\
\hline $\mathrm{Ba}$ & 15 & 186 & 66 \\
\hline $\mathrm{Sr}$ & 36 & 364 & 121 \\
\hline
\end{tabular}


the underlying rock type. A unique range of water chemistry evolves within each of the five rock groups (Table 1). Values of TDS can be used to compute the rate at which rivers transport chemical weathering products to the ocean and therefore chemical weathering rates at a point in time but not an annual rate. Even so, TDS values can be used to compare waters from different geologic terrains as a means of comparing chemical weathering rates. Mean TDS values for waters from the five areas are shown in Table 1. Waters with the highest mean TDS values evolve from areas underlain by Evaporite Facies rocks in the Eagle Valley and South Park followed by Minturn and Belden Formations in the Sangre de Cristo Range, Minturn and Belden Formations in the Flat Tops area, Minturn and Belden Formations in the Redcliff area, and Sangre de CristoFormation in the Sangre de Cristo Range. The areas underlain by Evaporite Facies rocks in the Eagle Valley and South Park are undergoing by far the most rapid rate of chemical weathering, supplying the most dissolved solids to the waters of the area. This is not surprising because these rocks contain evaporite minerals, particularly gypsum, which are readily soluble. Watersheds underlain by Pennsylvanian Sangre de CristoFormation in the Sangre de Cristo Range are undergoing the lowest rate of chemical weathering and supplying the lowest amounts of dissolved solids to the waters of the area. These rocks contain sandstones and conglomerates more resistance to weathering and lack the more soluble carbonate and evaporite minerals such as gypsum of the other rock groups.

Alkalinity of a solution is the capacity for solutes it contains to react with and neutralize acid (Hem, 1992). The property of alkalinity is determined by titration with a strong acid. Several different solute species may contribute to alkalinity, but for almost all natural fresh waters, the alkalinity is produced by the dissolved carbon dioxide species, bicarbonate and carbonate (Hem, 1992). Alkalinity in this study is reported as equivalent amounts of bicarbonate and is a measure of the capacity of the water to react with and consume acid. If an area is affected by introduced acidity from sources such as acid mine drainage or acid rain, the alkalinity will consume the introduced acid. If all the alkalinity is consumed and acidity is still being introduced, the acidity of the water will increase. The higher the alkalinity value, the greater the capacity of the water to consume acid. The mean alkalinity values of waters from areas underlain by the five rock groups range from 179 to $402 \mathrm{mg} / \mathrm{L}$ as $\mathrm{HCO}_{3}{ }^{-}$(Table 1). The waters 
with the highest alkalinity values are from areas underlain by Minturn and Belden Formations in the Flat Tops area, followed by Evaporite Facies in the Eagle Valley and South Park, Minturn and Belden Formations in the Redcliff area, and Minturn and Belden Formations in the Sangre de Cristo Range. The lowest alkalinity values are from areas underlain by Sangre de Cristo Formation in the Sangre de Cristo Range. The waters from areas underlain by Minturn and Belden Formations and the Evaporite Facies are very well buffered and have large capacity to neutralize acidity.

Mean $\mathrm{pH}$ values of waters from areas underlain by the five rock groups are all alkaline and range from 7.82 to 8.33 (Table 1). In addition to rock type, $\mathrm{pH}$ values in these headwater streams are affected by the amount of melting snow runoff as a component of the total flow and the time of contact of water and rock. The snow runoff will generally lower the $\mathrm{pH}$, and the time of contact of water and rock will generally increase the $\mathrm{pH}$ value. In addition, high biotic activity in the soil zone may release organic acids and may lower $\mathrm{pH}$. The lowest mean $\mathrm{pH}$ values are from Belden and Minturn Formations in the Flat Tops area and the Sangre de Cristo Formation in the Sangre de Cristo Range. Both areas have the large components of snow runoff which probably accounts for the lower $\mathrm{pH}$ values compared to the remaining rock groups.

Mean concentrations of $\mathrm{Si}$ in waters from areas underlain by the five rock groups range from 3.3 to $7.5 \mathrm{mg} / \mathrm{L}$ (Table 1). These values are low for four of the rock groups compared to average fresh water of $6.1 \mathrm{mg} / \mathrm{L}$ (Table 3). The highest mean value is from areas underlain by evaporites, probably because these rocks contain fine-grained silicate minerals with high surface areas, particularly susceptible to the dissolution of silica. The other four rock types contain coarser grain-size silicate minerals which are more resistant to weathering.

Mean concentrations of $\mathrm{Cu}, \mathrm{Zn}, \mathrm{Fe}, \mathrm{Mn}$, and $\mathrm{Mn}$ in waters from the five rock groups are low (Table 1), compared to average fresh water (Table 3). Mean Mo concentrations are low except from areas underlain by Minturn and Belden Formations from the Sangre de Cristo Range and Evaporite Facies from Eagle Valley and South Park. Mean U is high for all rock groups except the Sangre de Cristo Formation and mean $\mathrm{Cr}$ and $\mathrm{Ni}$ concentrations are high for the five rock groups (Table 1). Mean sulfate concentrations are high for the five rock groups compared to fresh water except for waters from areas underlain by Minturn and Beldon Formations in the 
Flat Tops area and the Sangre de Cristo Formation in the Sangre de Cristo Range. Waters from areas underlain by Minturn and Beldon Formations in the Flat Top area is low in sulfate probably because of the large component of snow melt in the waters. The source of sulfate in waters is probably gypsum in all the rock types except for waters from the Sangre de Cristo Formation in the Sangre de Cristo Range. By far the highest mean sulfate in waters $(155 \mathrm{mg} / \mathrm{L})$ is from areas underlain by Evaporite Facies in Eagle Valley and South Park, which contains the highest amounts of gypsum. Mean Li concentrations are high except from areas underlain by Minturn and Belden Formations in the Eagle Valley. Mean nitrate values are low for all waters suggesting little or no anthropogenic contamination.

A comparison of water chemistry from the three areas underlain by Minturn and Belden Formations shows that waters from areas underlain by Minturn and Belden Formations in the Sangre de Cristo Range have the highest TDS values and sulfate concentrations (Table 1). The likely source of the sulfate is gypsum, so these rocks probably contain more evaporite minerals, particularly gypsum, than the other two areas. The waters from the Flat Tops area contained the lowest amount of sulfate, and this area probably contains the least amount of evaporite minerals of the three areas containing Minturn and Belden Formation rocks. But waters from the Flat Top area contain the highest alkalinity (Table 1) indicating that these waters are in contact with more carbonate rocks than the other two areas.

\section{Chemical Modeling of the Waters}

To gain understanding of processes such as speciation of elements and identification of minerals that may control the concentration, mobility, and attenuation of elements in the stream waters, chemical modeling of the waters was carried out using PHREEQC (Parkhurst, 1995). The modeling program assumes mineral-solution equilibrium. For some chemical reactions, particularly with slow kinetics, this may not be the case. Except for Al, most of the cations in the stream waters occur mostly as simple cations and the anions as chloride, sulfate, carbonate, and bicarbonate complexes (Table 8). Si occurs as the uncharged specie $\mathrm{H}_{4} \mathrm{SiO}_{4}{ }^{0}$. In addition, the state of saturation of the waters with mineral phases were calculated. Saturation indices were 
Table 8. Dominant species of selected elements in waters

\begin{tabular}{cc}
\hline Element & Specie \\
\hline \hline $\mathrm{Ca}$ & $\mathrm{Ca}^{2+}$ \\
$\mathrm{Mg}$ & $\mathrm{Mg}^{2+}$ \\
$\mathrm{Na}$ & $\mathrm{Na}^{+}$ \\
$\mathrm{K}$ & $\mathrm{K}^{+}$ \\
$\mathrm{S}$ & $\mathrm{SO}_{4}{ }^{2-}$ \\
$\mathrm{C}$ & $\mathrm{HCO}_{3}{ }^{-}$ \\
$\mathrm{Cl}$ & $\mathrm{Cl}^{-}$ \\
$\mathrm{F}$ & $\mathrm{F}^{-}$ \\
$\mathrm{Si}$ & $\mathrm{H}_{4} \mathrm{SiO}_{4}{ }^{0}$ \\
$\mathrm{Al}$ & $\mathrm{Al}^{-}(\mathrm{OH})_{4}{ }^{-}$ \\
$\mathrm{Fe}$ & $\mathrm{Fe}^{2+}, \mathrm{FeCO}_{3}{ }^{-}, \mathrm{Fe}(\mathrm{OH})_{3}{ }^{0}$ \\
$\mathrm{Mn}$ & $\mathrm{Mn}^{3+}, \mathrm{MnCO}_{3}{ }^{0}$ \\
\hline
\end{tabular}


calculated for a suite of minerals to determine if concentrations of trace metals in water were controlled by mineral phases. The saturation index is a convenient means of expressing saturation states of minerals (Barnes and Clark, 1969) where:

$$
\mathrm{SI}=\log _{10} \mathrm{IAP} / \mathrm{K}_{\mathrm{T}}
$$

In the expression, $\mathrm{SI}$ is the saturation index, IAP is the ion activity product, and $\mathrm{K}_{\mathrm{T}}$ is the equilibrium constant of the dissolution reaction at the temperature of the sample. Mineral phases are supersaturated at $\mathrm{SI}>0$, saturated at $\mathrm{SI}=0$, and undersaturated at $\mathrm{SI}<0$.

Each water sample was modeled and the results for selected minerals are shown in Table 9. Waters from areas underlain by the five rock groups are mostly supersaturated or near saturated with respect to calcite. Many are supersaturated or near saturation with respect to barite and dolomite. These minerals appear to control the solubility of $\mathrm{Ca}, \mathrm{Mg}, \mathrm{Ba}$, and alkalinity. Another mineral which has an influence on the control of species in water is chalcedony. The waters from all the rock groups are slightly undersaturated with respect to chalcedony, which appears to control the amount of dissolved silica in the waters. The waters are all undersaturated with respect to other minerals such as siderite, gypsum, fluorite, sepiolite, and rhodochrosite except for one water supersaturated with respect to sepiolite from Evaporite Facies rocks in South Park. Of the five rock groups, waters from Evaporite Facies rocks in the Eagle Valley and South Park come closest to saturation with respect to gypsum, which is not surprising since these rocks contain abundant gypsum.

\section{Comparison of Water Chemistry of Two Streams From Above and Below Contact with Evaporite Facies Rocks and Potential Environmental Problems Associated with Construction in the Eagle Valley}

The changes of water chemistry of a stream as it crosses the contact and comes into contact with Evaporite Facies rock are shown for Eby and Beaver Creeks (fig.10). Upper Eby 
Table 9. Saturation indices for selected minerals for waters from Permian and Pennsylvanian Rocks, Western Colorado

Site Barite Calcite Chalcedony Dolomite Gypsum Rhodochrosite Sepiolite Siderite

Minturn and Belden Formations in the Redcliff Area

$\begin{array}{lllllllll}\text { CC43 } & 0.56 & 1.14 & -0.32 & 1.56 & -1.31 & -1.87 & -2.02 & -1.64 \\ \text { CC44 } & 0.41 & 1.07 & -0.33 & 1.41 & -1.4 & -2.52 & -2.19 & -1.64 \\ \text { CC45 } & -1.28 & 0.37 & -0.48 & -0.65 & -3.13 & -1.06 & -6.78 & -1.24 \\ \text { CC46 } & -1.41 & 0.21 & -0.4 & -1.02 & -3.38 & -3.01 & -7.23 & -2.8 \\ \text { CC47 } & -1.02 & 0.89 & -0.4 & 0.52 & -3.18 & -0.86 & -4.51 & -1.31 \\ \text { CC48 } & -1.39 & 0.23 & -0.4 & -1.07 & -3.27 & -1.75 & -7.52 & -1.9 \\ \text { CC49 } & -1.33 & 0.34 & -0.39 & -1.06 & -3.29 & -1.63 & -7.24 & -2.66 \\ \text { CC50 } & -1.16 & 0.19 & -0.31 & -1.3 & -3.29 & -3.96 & -6.97 & -2.72\end{array}$

Minturn and Belden Formations in the Flat Top Area

$\begin{array}{lllllllll}\text { CC05 } & 0.29 & 0.63 & -0.44 & 1.08 & -2.65 & -2.8 & -2.04 & -2.85 \\ \text { CC06 } & 0.54 & 1.04 & -0.35 & 1.51 & -1.46 & -2.35 & -1.98 & -2.95 \\ \text { CC07 } & -0.2 & 0.78 & -0.54 & 1.09 & -2.62 & -2.31 & -2.6 & -2.1 \\ \text { CC08 } & -0.31 & 0.9 & -0.56 & 1.65 & -2.85 & -1.26 & -1.37 & -1.45 \\ \text { CC09 } & -0.22 & 1.15 & -0.57 & 1.84 & -2.62 & -2.67 & -1.06 & -1.87 \\ \text { CC10 } & -0.76 & 0.13 & -0.61 & -0.22 & -2.93 & -1.62 & -6.12 & -2.25 \\ \text { CC11 } & -0.79 & 0.63 & -0.57 & 0.26 & -3.39 & -2.9 & -3.71 & -2.11\end{array}$

Minturn and Belden Formations in the Sangre de Cristo Range

$\begin{array}{llllccccr}\text { CC13 } & -0.09 & 0.69 & -0.42 & 1.29 & -2.3 & -2.29 & -1.59 & -1.58 \\ \text { CC14 } & -0.78 & 0.64 & -0.59 & 1 & -3.04 & -2.18 & -2.73 & -1.97 \\ \text { CC26 } & 0.32 & 0.82 & -0.37 & 1.18 & -1.4 & -2.59 & -2.29 & -1.76 \\ \text { CC27 } & 0.41 & -0.18 & -0.27 & -0.85 & -1.31 & -3.43 & -6.35 & -2.77 \\ \text { CC28 } & 0.22 & 1.28 & -0.22 & 2.33 & -1.6 & -1.7 & -0.04 & -1.11 \\ \text { CC29 } & 0.23 & 0.98 & -0.26 & 1.57 & -1.58 & -0.89 & -1.1 & -1.16\end{array}$




\begin{tabular}{|c|c|c|c|c|c|c|c|c|}
\hline Site & Barite & Calcite & Chalcedony & Dolomite & Gypsum & Rhodochrosite & Sepiolite & Siderite \\
\hline \multicolumn{9}{|c|}{ Evaporite Facies of Eagle Valley and South Park } \\
\hline $\mathrm{CC} 01$ & 0.62 & 1.31 & -0.07 & 2.45 & -0.68 & -0.09 & -0.61 & -0.77 \\
\hline $\mathrm{CC} 02$ & 0.1 & 0.52 & -0.02 & -0.36 & -2.39 & -1.34 & -2.96 & -1.69 \\
\hline $\mathrm{CC} 03$ & 0.03 & 1.34 & -0.37 & 2.45 & -1.62 & -1.13 & 0.2 & -1.67 \\
\hline CC31 & -0.19 & 0.17 & -0.43 & -0.15 & -2.34 & -1.23 & -3.66 & -1.03 \\
\hline CC33 & 0.33 & 1.14 & -0.52 & 1.79 & -1.18 & -0.06 & -1.61 & -0.57 \\
\hline CC34 & 0.87 & 1.21 & -0.3 & 1.76 & -1.08 & -1.89 & -1.46 & -1.42 \\
\hline CC36 & 0.47 & 1.44 & -0.18 & 2.65 & -1.02 & -0.87 & -0.26 & -0.48 \\
\hline CC38 & 3.52 & 0.87 & 0.04 & 1.23 & -0.31 & 0.31 & -2.87 & -1.28 \\
\hline CC39 & 0.22 & 0.2 & -0.24 & -0.1 & -2.22 & -3.11 & -3.84 & -2.37 \\
\hline CC40 & 0.29 & 0.58 & -0.22 & 0.21 & -0.91 & -3.49 & -4.36 & -2.23 \\
\hline CC41 & 0.67 & 1.28 & -0.1 & 2.01 & -1.13 & -1.01 & -1.39 & -0.7 \\
\hline
\end{tabular}

Sangre de Cristo Formation in the Sangre de Cristo Range

$\begin{array}{lllllllll}\mathrm{CC} 15 & -1.6 & -1.26 & -0.37 & -2.96 & -4.04 & -2.65 & 9.16 & -1.86 \\ \mathrm{CC} 16 & -0.95 & -0.85 & -0.28 & -2.46 & -3.5 & -2.67 & -7.68 & -2.88 \\ \mathrm{CC} 17 & -0.41 & -0.11 & -0.78 & -0.9 & -2.91 & -2.2 & -5.36 & -1.03 \\ \mathrm{CC} 18 & -0.2 & 1.01 & -0.99 & 1.6 & -2.09 & -1.01 & -1.37 & -1.03 \\ \mathrm{CC} 19 & 0.1 & 0.09 & -0.89 & -0.33 & -2.12 & -2.79 & -5.28 & -2.59 \\ \mathrm{CC} 20 & -0.37 & 0.48 & -0.3 & 0.15 & -3.23 & -2.29 & -3.41 & -2.27 \\ \mathrm{CC} 21 & -0.38 & -0.47 & -0.7 & -1.62 & -3.12 & -3.07 & -6.87 & -2.57 \\ \mathrm{CC} 22 & -0.75 & -0.56 & -0.7 & -1.73 & -3.19 & -4.6 & -7.19 & -3.03 \\ \mathrm{CC} 23 & -0.48 & -0.16 & -0.33 & -1.06 & -3.24 & -3.46 & -5.67 & -2.79 \\ \mathrm{CC} 24 & -0.65 & 0.09 & -0.4 & -0.47 & -3.32 & -2.53 & -5.1 & -2.7 \\ \mathrm{CC} 25 & -0.19 & 0.5 & -0.24 & 0.57 & -2.97 & -4.08 & -3.04 & -1.91\end{array}$

Eby and Beaver Creeks

\begin{tabular}{lllllllll}
$\mathrm{CC} 32$ & -1.42 & -1.25 & -0.46 & -2.81 & -3.99 & -2.59 & -6.58 & -2.56 \\
$\mathrm{CC} 37$ & -1.15 & 0.28 & -0.09 & 0.06 & -3.18 & -0.99 & -4.79 & -1.65 \\
\hline
\end{tabular}




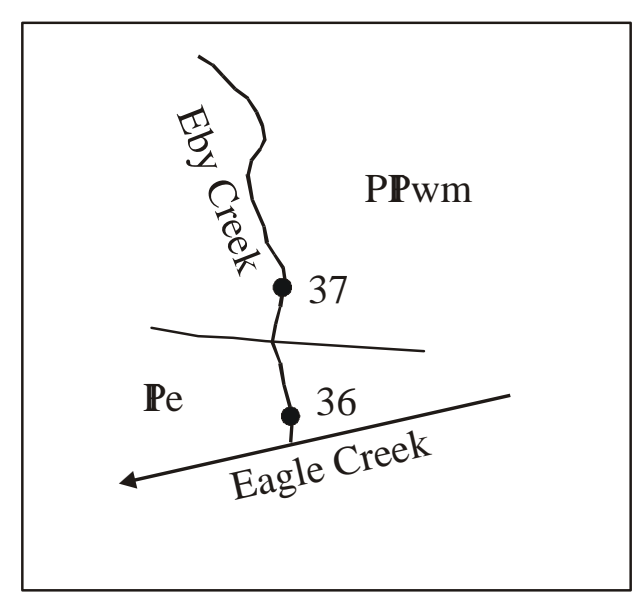

\begin{tabular}{l|ll} 
& Site 37 & Site 36 \\
\hline & & \\
$\mathrm{pH}$ & 7.36 & 8.30 \\
TDS & 482.7 & 841.5 \\
Calcium & 84.1 & 141.8 \\
Alkalinity & 524 & 562 \\
Sulfate & 93.6 & 321
\end{tabular}

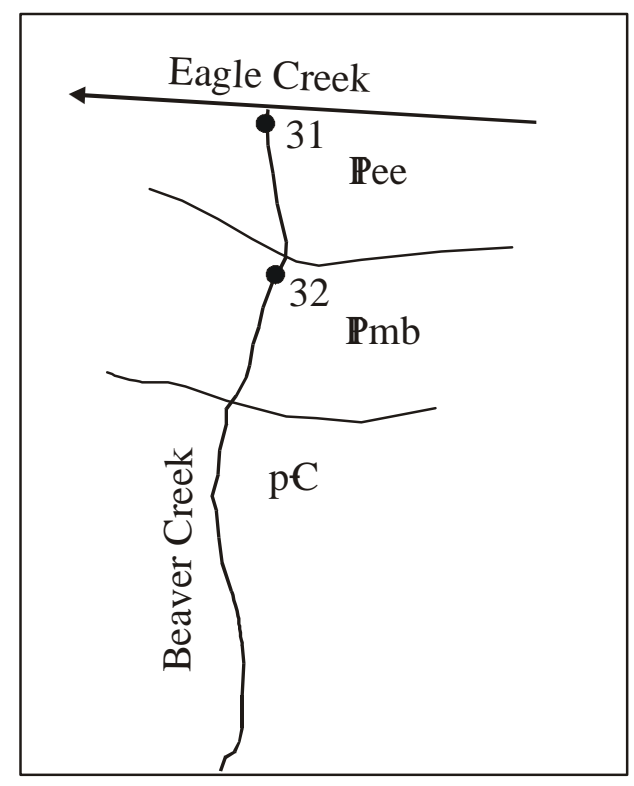

\begin{tabular}{l|ll} 
& Site 32 & Site 31 \\
\hline & & \\
pH & 7.55 & 8.06 \\
TDS & 55.7 & 169.3 \\
Calcium & 6.8 & 30.1 \\
Alkalinity & 78 & 177 \\
Sulfate & 2.15 & 30.3
\end{tabular}

Figure 10. Increases in water chemistry from above to below contact with Evaporite Facies rocks of two streams. Units for conductivity in $\mu \mathrm{S} / \mathrm{cm}$, alkalinity in $\mathrm{mg} / \mathrm{L}$ bicarbonate, and calcium and sulfate in $\mathrm{mg} / \mathrm{L}$. 
Creek is underlain by Permian and Pennsylvanian Weber Sandstone and Maroon Formation and to a lesser extent by Cretaceous Dakota Sandstone and Colorado Group (Tweto, 1979). Site 37 (fig. 10) represents the stream water chemistry above the contact with Evaporite Facies rocks. Below this site the stream crosses into Evaporite Facies rocks and site 36 shows the impact of these rocks on water chemistry. TDS, $\mathrm{pH}, \mathrm{Ca}$, alkalinity, and sulfate all increase significantly. The largest increase is in sulfate $(243 \%)$. The source of the sulfate is likely gypsum within the Evaporite Facies rocks. Ca concentration increases (69\%), but not as much as the sulfate concentration. Congruent dissolution of gypsum would cause $\mathrm{Ca}$ and sulfate to increase similarly, but this is not the case. The stream water above site 37 is saturated with respect to calcite (table 9), which controls the Ca concentrations. As Ca is released by the dissolution of gypsum, much of this extra $\mathrm{Ca}$ is precipitated as calcite. So the increase in $\mathrm{Ca}$ does not keep pace with the increase in sulfate. The significant change in water chemistry between site 37 and site 36 illustrates the degradation of the waters resulting from contact with Evaporite Facies rocks and, in particular, gypsum. Increase in sulfate concentration is the main impact on the stream water chemistry. TDS values increase to a lessor extent (74\%).

Upper Beaver Creek above site 32 drains areas underlain mainly by Precambrian rocks and to a lesser extent Minturn and Belden Formations rocks (Tweto, 1979). The dramatic increase in water chemistry can be seen between site 32 and site 31 after the stream comes into contact with Evaporite Facies rocks (fig.10). Again, there is a general degradation of stream water chemistry.

Within the Eagle River Valley from westward from the towns of Avon to Gypsum, significant construction of ski areas, golf courses, and houses are taking place at a rapid pace. Much of the water for snow making for the ski areas and irrigation for golf courses and homes is being obtained from tributaries of Eagle River. Much of this new construction is on Evaporite Facies rocks. The use of the water, particularly for snow making and irrigation, will probably impact the water chemistry by causing an increase in TDS in the Eagle River and the downstream Colorado River. Some of the tributaries have formed wide flat areas at their mouths before entering the Eagle River, mainly because of the presence of easily eroded Evaporite Facies rocks. These wide flat areas are ideal locations of golf courses with surrounding homes. 
This land use will require large amounts of water for irrigation and has the potential to significantly impact the water quality in terms of an increase in TDS of the Eagle River and the downstream Colorado River. Irrigation of the golf courses and yards of the homes will cause chemical degradation of the Eagle River during the summer. The melting of snow made by snow making will also cause chemical degradation of the Eagle River in the spring in this area.

\section{Summary and Conclusions}

This study determines ranges and means of baseline geochemistry of stream and spring waters that evolve within each of five rock groups of Permian and Pennsylvanian rocks in western Colorado. By comparing the geochemistry of the waters that evolve in each of the five rock groups, a rationale can be developed for characterizing and ranking the rock groups as to their release of TDS (a measure of chemical weathering) and their acid-neutralizing capacities. Also, processes responsible for the control and mobility of elements in water and the potential environmental impact of development in the Eagle Valley are discussed. The following are the most significant conclusions based on these results:

- 1 . The baseline geochemistry of stream and spring waters evolving in the headwater areas depends on the chemical composition of the underlying rock type. Within each rock compositional type, a unique range of water compositions evolve. Other factors such as annual precipitation, temperature, topographic setting, character of minerals (e.g., grain size and crystallinity), and biotic activity can be important, but mainly influence the rates of chemical reactions and not the type of elements present in the waters.

- 2. The waters that evolve in these five rock groups are mainly $\mathrm{Ca}^{2+}-\mathrm{HCO}_{3}^{-}$type waters, with alkaline $\mathrm{pH}$ values and high TDS values. Dominant species present in the water samples are $\mathrm{Ca}^{2+}, \mathrm{Mg}^{2+}, \mathrm{Na}^{+}, \mathrm{K}^{+}, \mathrm{SO}_{4}{ }^{2-}, \mathrm{HCO}_{3}{ }^{-}, \mathrm{Cl}^{-}, \mathrm{F}^{-}, \mathrm{H}_{4} \mathrm{SiO}_{4}{ }^{0}, \mathrm{Al}(\mathrm{OH})_{4}{ }^{-}, \mathrm{Fe}^{2+}$, and $\mathrm{Mn}^{2+}$. 
- 3. TDS values, which are an approximate measure of the chemical weathering rates, indicate that waters with the highest TDS values evolve from watersheds underlain by Evaporite Facies rocks in Eagle Valley and South Park. This is not surprising because these formations contain soluble evaporite minerals such as gypsum. Waters with the lowest TDS values evolve from watersheds underlain by the Sangre de Cristo Formation. These rocks contain abundant coarse grained sediments which are more resistant to weathering.

- 4. Alkalinity is a measure of the acid-neutralizing capacity of waters to introduced acidification. The waters with the highest alkalinity values are from areas underlain by Minturn and Belden Formations in the Eagle Valley, followed by Evaporite Facies in the Eagle Valley and South Park, Minturn and Belden Formations in the Redcliff area, and Minturn and Belden Formations in the Sangre de Cristo Range. The lowest alkalinity values are from areas underlain by Sangre de Cristo Formation in the Sangre de Cristo Range. All the waters contain significant alkalinity and are well buffered. The waters from the Minturn and Belden Formations and the Evaporite Facies have large capacity to neutralize acidity.

- 5. Mean values for $\mathrm{pH}$ of waters from areas underlain by the five rock groups are all alkaline and range from 7.82 to 8.33. The lowest mean $\mathrm{pH}$ values are from Belden and Minturn Formations in the Flat Tops area and the Sangre de Cristo Formation in the Sangre de Cristo Range. Both areas have large components of snow runoff which probably accounts for the lower $\mathrm{pH}$ values compared to the remaining rock groups.

- 6. The mean sulfate values are high compared to average fresh water from all the areas except waters from the Minturn and Beldon Formations in the Flat Tops area and the Sangre de Cristo Formation in the Sangre de Cristo Range. By far the highest sulfate values are from areas underlain by Evaporite Facies in Eagle Valley and South Park, mainly because of the presence of gypsum. 
- 7. Mean concentrations of $\mathrm{Cu}, \mathrm{Zn}, \mathrm{Fe}, \mathrm{Mn}$, and $\mathrm{Mn}$ in waters from the five rock groups are low and the mean concentrations of $\mathrm{Ni}$ and $\mathrm{Cr}$ are high compared to average fresh water. Mean concentrations of $U$ is high for all rock groups except the Sangre de Cristo Formation.

- 8. Evaporite minerals are present in the Minturn and Belden Formations in the Redcliff area, the Flat Tops areas, and Sangre de Cristo Range. The amounts vary but are generally much less than Evaporite Facies rocks.

- 9. Development of golf courses, homes, and ski areas in the Eagle Valley between Avon and Gypsum has led to the diversion of water, particularly of tributaries of the Eagle River, for irrigation and snow making. In areas where this development overlies Evaporite Faies rocks, the irrigation and snow making has probably lead to an increase in TDS and a lowering of water quality of the Eagle River and downstream Colorado River.

The unique geochemical baselines from the five rock groups demonstrates the importance of rock composition in determining the types of waters that are evolving in headwater areas. These geochemical baselines provide ranges and means of values that approximate the natural baseline geochemistry of the stream and spring waters in these watersheds for each of the five rock groups. In addition, the comparison of these geochemical baselines with future baselines will allow the recognition of any significant changes in water quality that may occur. 


\section{References Cited}

Apodoaca, L.E., Driver, N.E., Stephens, V.C., and Spahr, N.E., 1996, Environmental setting and implications on water quality, Upper Colorado River Basin, Colorado and Utah: WaterResources Investigations Report 95-4263, 33 p.

Barnes, I. and Clark, F.E., 1969, Chemical properties of ground water and their corrosion and encrustation effects on wells: U.S. Geol. Survey Professional Paper 498-D, 58 p.

Colorado Climate Center, 1984, Colorado average annual precipitation 1951-1980: Compiled by Climate Center, Dept. Atmospheric Science, Colorado State Univ., Fort Collins, scale $1: 500,000$.

Curtis, B. F., 1958, Pennsylvanian paleotectonics of Colorado and adjacent areas, in Curtis, B. F., ed. Symposium on Pennsylvanian rocks of Colorado and adjacent areas: Rocky Mountain Association of Geologists, p. 9-12.

DeVoto, R. H., 1972, Pennsylvanian and Permian stratigraphy and tectonism in central Colorado: Quarterly of the Colorado School of Mines, v. 67, p. 139-185.

Edwards, T. K. and Glysson, G. D., 1988, Field methods for measurement of fluvial sediment: U.S. Geological Survey Open-File Report 86-531, 118 p.

Fishman, M.J. and Pyen, G., 1979, Determination of selected anions in water by ion chromatography: U.S. Geol. Survey Water Resources Invest. 79-101, 30 p.

Forstner, U. and Wittmann, G. T. W., 1979, Metal pollution in the aquatic environment: Springer 
Verlag, $486 \mathrm{p}$.

Hem, J.D., 1992, Study and interpretation of the chemical characteristics of natural water: U.S. Geological Survey Water-Supply Paper 2254, 263 p.

Hunt, C.B., 1974, Natural regions of the United States and Canada: San Francisco, W.H. Freeman and Company, $725 \mathrm{p}$.

Johnson, R. B., 1969, Geologic map of the Trinidad quadrangle, south-central Colorado: U.S. Geological Survey Misc. Geol. Inv. Map I-558.

Kuchler, A. W., 1965, Potential natural vegetation of the conterminous United States: American Geographical Society Special Publication no. 36.

Livingstone, D.A., 1963, Chemical composition of rivers and lakes: $6^{\text {th }}$ ed., U.S. Geological Survey Professional Paper 440-G, 64 p.

Mallory, W. W., 1971, The Eagle Valley Evaporite, northwest Colorado-a regional synthesis: U.S. Geological Survey Bulletin 1311-E, p. E1-E37.

Miller, W.R., 1999, Geochemical baselines and maps showing acid-neutralizing capacity and potential release of total dissolved solids of stream and spring waters from different rock compositional types from mountainous watersheds in the Gunnison, Uncompahgre, and Grand Mesa National Forest, Colorado: U.S. Geological Survey Open-File Report 99580, $107 \mathrm{p}$.

Orion Research, Inc., 1978, Analytical methods guide ( $9^{\text {th }}$ ed.): Cambridge, MA, 48 p.

Parkhurst, D.L., 1995, User's guide to PHREEQC - a computer program for speciation, reactionpath, advective-transport, and inverse geochemical calculations: U.S. Geological Survey 
Water-Resources Investigations Report 95-4227, 143 p.

Tweto, O., 1979, Geologic map of Colorado: U.S. Geological Survey Publication, scale $1: 1,500,000$.

U. S. Department of Agriculture, 1972, Natural vegetation, Colorado, scale 1:1,500,000. 
Appendix 1. Chemical analyses of waters from areas underlain by Permian and Pennsylvanian rocks, western Colorado. (PPsc) Sangre de CristoFormation, (PPwm) Weber Sandstone and Maroon Formation, (Pee) Evaporitic Facies, (Pe) Eagle Valley Formation, (Pmbe) Evaporitic Facies, (Pm) Minturn Formation, (Pmb) Minturn and Belden Formations, (MDr) Missippian and Devonian rocks, and (PC) Precambirian rocks (Tweto, 1979).

\begin{tabular}{|c|c|c|c|c|c|c|c|c|c|}
\hline \multirow[t]{2}{*}{ Site } & \multicolumn{3}{|c|}{ Latitude } & \multicolumn{3}{|c|}{ Longitude } & \multirow[t]{2}{*}{ Date } & \multirow[t]{2}{*}{ Flow } & \multirow[t]{2}{*}{ Comments } \\
\hline & deg. & $\min$. & sec. & deg. & $\min$. & sec. & & & \\
\hline \multicolumn{10}{|c|}{ Minturn and Belden Formations in the Redcliff Area } \\
\hline $\mathrm{CC} 05$ & 39 & 32 & 14 & 106 & 23 & 26 & $7 / 19 / 00$ & 3 gps & Rock Creek \\
\hline $\mathrm{CC} 06$ & 39 & 35 & 52 & 106 & 25 & 34 & $7 / 19 / 00$ & $10 \mathrm{gps}$ & Game Creek \\
\hline $\mathrm{CC} 07$ & 39 & 33 & 56 & 106 & 23 & 57 & $7 / 19 / 00$ & $5 \mathrm{cfs}$ & Two Elk Creek \\
\hline $\mathrm{CC} 08$ & 39 & 31 & 0 & 106 & 21 & 43 & $7 / 19 / 00$ & 10 gps & Willow Creek \\
\hline $\mathrm{CC} 09$ & 39 & 31 & 23 & 106 & 20 & 9 & $7 / 19 / 00$ & $3 \mathrm{cfs}$ & Lime Creek \\
\hline $\mathrm{CC} 10$ & 39 & 32 & 49 & 106 & 17 & 53 & $7 / 19 / 00$ & 2 gps & spring from wetland \\
\hline $\mathrm{CC} 11$ & 39 & 33 & 14 & 106 & 16 & 48 & $7 / 19 / 00$ & $5 \mathrm{gps}$ & stream \\
\hline \multicolumn{10}{|c|}{ Minturn and Belden Formations in the Flat Tops Area } \\
\hline $\mathrm{CC} 43$ & 39 & 45 & 49 & 107 & 41 & 36 & $8 / 24 / 00$ & $10 \mathrm{cfs}$ & Three Forks Creek \\
\hline $\mathrm{CC} 44$ & 39 & 45 & 47 & 107 & 41 & 34 & $8 / 24 / 00$ & $10 \mathrm{gps}$ & Rifle Creek \\
\hline $\mathrm{CC} 45$ & 39 & 48 & 57 & 107 & 41 & 49 & $8 / 24 / 00$ & 2 gps & G V Spring \\
\hline $\mathrm{CC} 46$ & 39 & 47 & 59 & 107 & 44 & 47 & $8 / 24 / 00$ & $2 \mathrm{qt} / \mathrm{sec}$ & spring \\
\hline $\mathrm{CC} 47$ & 39 & 46 & 13 & 107 & 45 & 29 & $8 / 24 / 00$ & 3 gps & Butler Creek \\
\hline $\mathrm{CC} 48$ & 39 & 47 & 46 & 107 & 45 & 18 & $8 / 24 / 00$ & $2 \mathrm{gps}$ & spring \\
\hline CC49 & 39 & 48 & 25 & 107 & 35 & 20 & $8 / 24 / 00$ & $1 \mathrm{qt} / \mathrm{sec}$ & Clark Cabin Spring \\
\hline $\mathrm{CC} 50$ & 39 & 48 & 19 & 107 & 35 & 28 & $8 / 24 / 00$ & $1 \mathrm{qt} / \mathrm{sec}$ & spring \\
\hline \multicolumn{10}{|c|}{ Minturn and Belden Formations in the Sangre de Cristo Range } \\
\hline $\mathrm{CC} 13$ & 38 & 19 & 30 & 105 & 49 & 12 & $8 / 14 / 00$ & 5 gps & South Prong Creek \\
\hline $\mathrm{CC} 14$ & 38 & 19 & 45 & 105 & 49 & 35 & $8 / 14 / 00$ & $2 \mathrm{cfs}$ & Middle Prong Creek \\
\hline $\mathrm{CC} 26$ & 38 & 19 & 2 & 105 & 45 & 17 & $8 / 16 / 00$ & $10 \mathrm{cfs}$ & Big Cottonwood Creek \\
\hline $\mathrm{CC} 27$ & 38 & 19 & 4 & 105 & 45 & 18 & $8 / 16 / 00$ & $2 \mathrm{qt} / \mathrm{sec}$ & Wolf Creek \\
\hline $\mathrm{CC} 28$ & 38 & 9 & 52 & 105 & 47 & 34 & $8 / 17 / 00$ & $10 \mathrm{gps}$ & Major Creek \\
\hline CC29 & 38 & 10 & 34 & 105 & 48 & 10 & $8 / 17 / 00$ & $2 \mathrm{cfs}$ & Garner Creek \\
\hline \multicolumn{10}{|c|}{ Evaporite Facies of Eagle Valley and South Park } \\
\hline $\mathrm{CC} 01$ & 39 & 2 & 5 & 105 & 58 & 57 & $7 / 18 / 00$ & $2 \mathrm{qt} / \mathrm{sec}$ & stream \\
\hline $\mathrm{CC} 02$ & 39 & 1 & 55 & 105 & 59 & 6 & $7 / 18 / 00$ & pump & well at campground \\
\hline $\mathrm{CC} 03$ & 38 & 59 & 6 & 105 & 59 & 3 & $7 / 18 / 00$ & 5 gps & stream \\
\hline $\mathrm{CC} 31$ & 39 & 37 & 51 & 106 & 31 & 16 & $8 / 21 / 00$ & $7 \mathrm{cfs}$ & lower Beaver Creek \\
\hline $\mathrm{CC} 33$ & 39 & 38 & 0 & 106 & 33 & 45 & $8 / 21 / 00$ & 7 gps & McCoy Creek \\
\hline $\mathrm{CC} 34$ & 39 & 39 & 12 & 106 & 35 & 5 & $8 / 21 / 00$ & $10 \mathrm{gps}$ & Berry Creek \\
\hline $\mathrm{CC} 36$ & 39 & 40 & 8 & 106 & 49 & 53 & $8 / 21 / 00$ & $2 \mathrm{cfs}$ & lower Eby Creek \\
\hline $\mathrm{CC} 38$ & 39 & 39 & 31 & 106 & 52 & 55 & $8 / 22 / 00$ & $1 \mathrm{qt} / \mathrm{sec}$ & spring in Cottonwood Creek \\
\hline CC39 & 39 & 31 & 54 & 106 & 55 & 31 & $8 / 22 / 00$ & $1 \mathrm{gps}$ & spring \\
\hline $\mathrm{CC} 40$ & 39 & 29 & 25 & 106 & 50 & 5 & $8 / 22 / 00$ & $1 \mathrm{gps}$ & spring \\
\hline $\mathrm{CC} 41$ & 39 & 35 & 10 & 107 & 3 & 6 & $8 / 23 / 00$ & 20 gps & Cottonwood Creek \\
\hline
\end{tabular}




\begin{tabular}{|c|c|c|c|c|c|c|c|c|c|}
\hline \multirow[t]{2}{*}{ Site } & \multicolumn{3}{|c|}{ Latitude } & \multicolumn{3}{|c|}{ Longitude } & \multirow[t]{2}{*}{ Date } & \multirow[t]{2}{*}{ Flow } & \multirow[t]{2}{*}{ Comments } \\
\hline & deg. & $\min$. & sec. & deg. & $\min$. & sec. & & & \\
\hline \multicolumn{10}{|c|}{ Sangre De Cristo Formation in the Sangre de Cristo Range } \\
\hline $\mathrm{CC} 15$ & 37 & 50 & 52 & 105 & 26 & 26 & $8 / 15 / 00$ & $3 \mathrm{cfs}$ & Mendano Creek \\
\hline $\mathrm{CC} 16$ & 37 & 56 & 26 & 105 & 27 & 32 & $8 / 15 / 00$ & 5 gps & Music Pass Creek \\
\hline $\mathrm{CC} 17$ & 37 & 59 & 42 & 105 & 29 & 26 & $8 / 15 / 00$ & $10 \mathrm{cfs}$ & South Colony Creek \\
\hline $\mathrm{CC} 18$ & 38 & 5 & 41 & 105 & 38 & 4 & $8 / 15 / 00$ & $5 \mathrm{cfs}$ & upper Middle Taylor Creek \\
\hline $\mathrm{CC} 19$ & 38 & 5 & 49 & 105 & 36 & 41 & $8 / 15 / 00$ & $5 \mathrm{cfs}$ & Middle Taylor Creek \\
\hline $\mathrm{CC} 20$ & 38 & 4 & 49 & 105 & 33 & 45 & $8 / 16 / 00$ & 4 gps & Alvarado Creek \\
\hline $\mathrm{CC} 21$ & 38 & 2 & 17 & 105 & 32 & 11 & $8 / 16 / 00$ & $8 \mathrm{cfs}$ & Horn Creek \\
\hline $\mathrm{CC} 22$ & 38 & 3 & 17 & 105 & 32 & 24 & $8 / 16 / 00$ & 5 gps & Dry Creek \\
\hline $\mathrm{CC} 23$ & 38 & 3 & 37 & 105 & 33 & 3 & $8 / 16 / 00$ & $3 \mathrm{cfs}$ & Hennequin Creek \\
\hline $\mathrm{CC} 24$ & 38 & 8 & 9 & 105 & 35 & 35 & $8 / 16 / 00$ & 1 gps & Gibson Creek \\
\hline $\mathrm{CC} 25$ & 38 & 7 & 54 & 105 & 35 & 54 & $8 / 16 / 00$ & 5 gps & Verde Creek \\
\hline \multicolumn{10}{|c|}{ Eby and Beaver Creeks } \\
\hline $\mathrm{CC} 32$ & 39 & 35 & 51 & 106 & 31 & 18 & $8 / 21 / 00$ & $6 \mathrm{cfs}$ & Beaver Creek \\
\hline $\mathrm{CC} 37$ & 39 & 41 & 30 & 106 & 49 & 52 & $8 / 22 / 00$ & $1 \mathrm{gps}$ & Eby Creek \\
\hline
\end{tabular}


Appendix 1. Chemical analyses of waters from areas underlain by Permian and Pennsylvanian rocks, western Colorado. (PPsc) Sangre de CristoFormation, (PPwm) Weber Sandstone and Maroon Formation, (Pee) Evaporitic Facies, (Pe) Eagle Valley Formation, (Pmbe) Evaporitic Facies, (Pm) Minturn Formation, (Pmb) Minturn and Belden Formations, (MDr) Missippian and Devonian rocks, and (PC) Precambirian rocks (Tweto, 1979).

\begin{tabular}{ccccccccc}
\hline Site & Geology & Temperature & $\mathrm{pH}$ & $\mathrm{TDS}$ & Conductivity & $\mathrm{Ca}$ & $\mathrm{Mg}$ & $\mathrm{Na}$ \\
\hline & Degree $\mathrm{C}$ & & $\mathrm{mg} / \mathrm{L}$ & $\mu \mathrm{S} / \mathrm{cm}$ & & $\mathrm{mg} / \mathrm{L}$ & $\mathrm{mg} / \mathrm{L}$ \\
\hline
\end{tabular}

Minturn and Belden Formations in the Redcliff Area

$\begin{array}{llcllllll}\mathrm{CC} 05 & \mathrm{Pmb} & 6.9 & 8.37 & 228.8 & 272 & 29.3 & 16.2 & 2.2 \\ \mathrm{CC} 06 & \mathrm{Pmb} & 7.7 & 8.31 & 426.1 & 564 & 85.6 & 19.4 & 2.3 \\ \mathrm{CC} 07 & \mathrm{Pmb} & 8.7 & 8.38 & 225.2 & 288 & 39.6 & 10.8 & 1.4 \\ \mathrm{CC} 08 & \mathrm{Pmb} & 11.3 & 8.57 & 221.0 & 269 & 32.1 & 16.0 & 1.4 \\ \mathrm{CC} 09 & \mathrm{Pmb} & 8.8 & 8.80 & 226.5 & 281 & 38.9 & 10.4 & 1.3 \\ \mathrm{CC} 10 & \mathrm{Pmb} & 14.1 & 7.47 & 260.0 & 314 & 47.3 & 10.2 & 1.3 \\ \mathrm{CC} 11 & \mathrm{Pmb} & 8.5 & 8.43 & 158.6 & 187 & 30.7 & 2.5 & 1.5\end{array}$

Minturn and Belden Formations in the Flat Tops Area

$\begin{array}{lcccccccc}\text { CC43 } & \text { Pm, MDr } & 7.4 & 8.31 & 479.0 & 633 & 108.2 & 17.6 & 2.0 \\ \text { CC44 } & \text { Pm, MDr } & 7.8 & 8.31 & 430.9 & 583 & 95.5 & 14.3 & 2.3 \\ \text { CC45 } & \text { Pm } & 10.2 & 7.63 & 270.3 & 333 & 64.6 & 2.0 & 0.9 \\ \text { CC46 } & \text { Pm } & 6.1 & 7.51 & 275.0 & 348 & 66.8 & 2.2 & 0.9 \\ \text { CC47 } & \text { Pm } & 9.6 & 8.06 & 313.8 & 377 & 73.3 & 3.1 & 1.3 \\ \text { CC48 } & \text { Pm } & 6.6 & 7.46 & 297.3 & 355 & 71.7 & 1.9 & 1.0 \\ \text { CC49 } & \text { Pmb } & 6.2 & 7.65 & 271.6 & 329 & 65.2 & 1.1 & 1.2 \\ \text { CC50 } & \text { Pmb } & 4.3 & 7.66 & 228.0 & 296 & 58.0 & 1.2 & 1.3\end{array}$

Minturn and Belden Formations in the Sangre de Cristo Range

$\begin{array}{lcccccccc}\mathrm{CC} 13 & \mathrm{Pmb} & 13.4 & 8.37 & 235.0 & 301 & 31.9 & 17.2 & 3.3 \\ \mathrm{CC} 14 & \mathrm{Pmb} & 12.6 & 8.32 & 196.5 & 235 & 30.5 & 10.6 & 1.3 \\ \mathrm{CC} 26 & \mathrm{Pmb} & 12 & 8.18 & 405.6 & 532 & 79.9 & 19.0 & 3.5 \\ \mathrm{CC} 27 & \mathrm{Pmb} & 7.9 & 7.11 & 469.0 & 632 & 90.6 & 24.4 & 4.7 \\ \mathrm{CC} 28 & \mathrm{Pm} & 10.7 & 8.56 & 444.9 & 552 & 72.0 & 30.3 & 4.5 \\ \mathrm{CC} 29 & \mathrm{Pm} & 14 & 8.38 & 356.0 & 473 & 67.0 & 17.2 & 3.3\end{array}$

\section{Evaporite Facies of Eagle Valley and South Park}

$\begin{array}{lcccccccc}\text { CC01 } & \text { Pmbe } & 23.3 & 8.01 & 1262.9 & 1416 & 212.9 & 67.3 & 59.9 \\ \text { CC02 } & \text { Pmbe } & 7.5 & 7.97 & 281.6 & 370 & 50.0 & 8.8 & 6.4 \\ \text { CC03 } & \text { Pmbe } & 22.5 & 8.65 & 362.0 & 462 & 66.5 & 18.0 & 6.0 \\ \text { CC31 } & \text { Pee, Pm, pC } & 11.7 & 8.06 & 169.3 & 232 & 30.1 & 7.0 & 3.8 \\ \text { CC33 } & \text { Pee, Pm } & 13.6 & 8.43 & 492.6 & 904 & 104.7 & 21.2 & 4.3 \\ \text { CC34 } & \text { Pe, PPm } & 12.8 & 8.36 & 563.2 & 720 & 125.6 & 17.9 & 3.9 \\ \text { CC36 } & \text { Pee, PPwm, others } & 18.4 & 8.30 & 841.5 & 994 & 141.8 & 45.2 & 31.7 \\ \text { CC38 } & \text { Pee } & 14.3 & 7.49 & 1757.3 & 2020 & 387.2 & 73.7 & 28.6 \\ \text { CC39 } & \text { Pee } & 6.7 & 7.87 & 232.1 & 292 & 39.4 & 11.1 & 2.7 \\ \text { CC40 } & \text { Pee } & 6 & 7.72 & 638.7 & 864 & 154.6 & 15.6 & 3.1 \\ \text { CC41 } & \text { Pee } & 13.5 & 8.14 & 675.5 & 841 & 142.4 & 26.1 & 5.7\end{array}$




\begin{tabular}{|c|c|c|c|c|c|c|c|c|}
\hline Site & Geology & Temperature & $\mathrm{pH}$ & TDS & Conductivity & $\mathrm{Ca}$ & $\mathrm{Mg}$ & $\mathrm{Na}$ \\
\hline & & Degree C & & $\mathrm{mg} / \mathrm{L}$ & $\mu \mathrm{S} / \mathrm{cm}$ & & $\mathrm{mg} / \mathrm{L}$ & $\mathrm{mg} / \mathrm{L}$ \\
\hline \multicolumn{9}{|c|}{ Sangre De Cristo Formation in the Sangre de Cristo Range } \\
\hline $\mathrm{CC} 15$ & PPsc & 10.4 & 7.54 & 58.3 & 63 & 6.9 & 1.9 & 1.8 \\
\hline $\mathrm{CC} 16$ & PPsc, Pm & 13 & 7.13 & 123.2 & 147 & 21.1 & 2.5 & 2.5 \\
\hline $\mathrm{CC} 17$ & PPsc & 12.9 & 8.10 & 98.8 & 126 & 17.5 & 2.4 & 1.3 \\
\hline $\mathrm{CC} 18$ & PPsc, Pmb & 16.3 & 8.99 & 167.5 & 237 & 32.3 & 7.2 & 1.2 \\
\hline CC19 & PPsc, Pmb & 11.8 & 8.01 & 169.0 & 234 & 32.0 & 7.0 & 1.4 \\
\hline $\mathrm{CC} 20$ & PPsc, Pmb & 9.8 & 8.18 & 180.8 & 216 & 33.7 & 4.0 & 3.9 \\
\hline $\mathrm{CC} 21$ & PPsc & 9.6 & 7.65 & 110.0 & 140 & 19.7 & 3.2 & 1.2 \\
\hline $\mathrm{CC} 22$ & PPsc & 11.8 & 7.53 & 110.1 & 142 & 19.1 & 3.4 & 1.0 \\
\hline $\mathrm{CC} 23$ & PPsc & 7.9 & 7.63 & 165.4 & 208 & 31.0 & 4.7 & 2.1 \\
\hline $\mathrm{CC} 24$ & PPsc & 12.8 & 7.73 & 181.3 & 223 & 34.0 & 5.1 & 2.5 \\
\hline $\mathrm{CC} 25$ & PPsc & 10.9 & 8.01 & 246.1 & 294 & 39.4 & 10.6 & 5.7 \\
\hline \multicolumn{9}{|c|}{ Eby and Beaver Creeks } \\
\hline $\mathrm{CC} 32$ & $\mathrm{Pm}, \mathrm{pC}$ & 11.5 & 7.55 & 55.7 & 67 & 6.8 & 2.4 & 1.4 \\
\hline CC37 & PPwm & 9.5 & 7.36 & 482.7 & 593 & 84.1 & 20.5 & 12.4 \\
\hline
\end{tabular}


Appendix 1. Chemical analyses of waters from areas underlain by Permian and Pennsylvanian rocks, western Colorado. (PPsc) Sangre de CristoFormation, (PPwm) Weber Sandstone and Maroon Formation, (Pee) Evaporitic Facies, (Pe) Eagle Valley Formation, (Pmbe) Evaporitic Facies, (Pm) Minturn Formation, (Pmb) Minturn and Belden Formations, (MDr) Missippian and Devonian rocks, and (PC) Precambirian rocks (Tweto, 1979).

\begin{tabular}{|c|c|c|c|c|c|c|c|c|}
\hline Site & $\mathrm{K}$ & $\mathrm{Si}$ & Alkalinity & $\mathrm{SO}_{4}$ & $\mathrm{Cl}$ & $\mathrm{F}$ & $\mathrm{N}$ & $\mathrm{Al}$ \\
\hline & $\mathrm{mg} / \mathrm{L}$ & $\mathrm{mg} / \mathrm{L}$ & $\mathrm{mg} / \mathrm{L} \mathrm{HCO}_{3}$ & $\mathrm{mg} / \mathrm{L}$ & $\mathrm{mg} / \mathrm{L}$ & $\mathrm{mg} / \mathrm{L}$ & $\mathrm{mg} / \mathrm{L}$ & \\
\hline \multicolumn{9}{|c|}{ Minturn and Belden Formations in the Redcliff Area } \\
\hline $\mathrm{CC} 05$ & 1.13 & 3.7 & 324 & 16.3 & $<1$ & $<0.05$ & $<0.05$ & 3.2 \\
\hline $\mathrm{CC} 06$ & 0.89 & 4.7 & 393 & 119 & $<1$ & 0.05 & $<0.05$ & \\
\hline $\mathrm{CC} 07$ & 0.53 & 3.1 & 317 & 13.1 & $<1$ & $<0.05$ & $<0.05$ & \\
\hline $\mathrm{CC} 08$ & 0.61 & 3.3 & 319 & 9.94 & $<1$ & $<0.05$ & $<0.05$ & \\
\hline CC09 & 0.51 & 3.0 & 320 & 14.3 & $<1$ & $<0.05$ & 0.08 & \\
\hline CC10 & $<0.5$ & 3.1 & 389 & 5.80 & $<1$ & $<0.05$ & 0.08 & \\
\hline CC11 & $<0.5$ & 2.9 & 239 & 2.46 & $<1$ & $<0.05$ & $<0.05$ & \\
\hline
\end{tabular}

Minturn and Belden Formations in the Flat Tops Area

$\begin{array}{lcccccccc}\text { CC43 } & 0.52 & 5.0 & 412 & 143 & <1 & 0.10 & 0.33 & 2.23 \\ \text { CC44 } & 0.55 & 4.9 & 383 & 124 & 1.14 & 0.08 & 0.26 & 2.04 \\ \text { CC45 } & <0.5 & 3.7 & 398 & 2.60 & <1 & <0.05 & 0.34 & 1.52 \\ \text { CC46 } & <0.5 & 3.9 & 405 & 1.39 & <1 & <0.05 & 0.87 & 0.90 \\ \text { CC47 } & <0.5 & 4.4 & 465 & 2.20 & <1 & 0.06 & <0.05 & 1.23 \\ \text { CC48 } & <0.5 & 4.0 & 440 & 1.74 & <1 & <0.05 & 0.45 & 1.80 \\ \text { CC49 } & <0.5 & 4.0 & 402 & 1.74 & <1 & <0.05 & <0.05 & 1.95 \\ \text { CC50 } & <0.5 & 4.6 & 326 & 1.83 & <1 & <0.05 & 0.49 & 1.39\end{array}$

Minturn and Belden Formations in the Sangre de Cristo Range

$\begin{array}{lllllcccc}\text { CC13 } & 0.64 & 4.7 & 285 & 36.3 & <1 & 0.07 & <0.05 & 6.29 \\ \text { CC14 } & 0.91 & 3.1 & 291 & 6.22 & <1 & <0.05 & <0.05 & 1.74 \\ \text { CC26 } & 1.30 & 5.1 & 295 & 151 & 1.03 & 0.13 & 0.07 & 1.20 \\ \text { CC27 } & 1.20 & 5.6 & 350 & 169 & 1.25 & 0.12 & <0.05 & 0.88 \\ \text { CC28 } & 1.36 & 7.0 & 444 & 110 & 1.10 & 0.08 & <0.05 & 4.07 \\ \text { CC29 } & 3.16 & 7.0 & 294 & 113 & <1 & 0.15 & <0.05 & 2.78\end{array}$

Evaporite Facies of Eagle Valley and South Park

$\begin{array}{lcccccccc}\text { CC01 } & 5.61 & 13.7 & 538 & 615 & 24.0 & 0.9 & <0.05 & 4.26 \\ \text { CC02 } & 0.83 & 9.8 & 373 & 18.6 & 3.79 & 0.16 & <0.05 & 2.61 \\ \text { CC03 } & 0.97 & 7.2 & 307 & 111 & 1.30 & 0.09 & <0.05 & 7.20 \\ \text { CC31 } & 0.95 & 4.4 & 177 & 30.3 & 5.74 & <0.05 & 0.27 & 8.21 \\ \text { CC33 } & 1.23 & 3.8 & 281 & 216 & 3.18 & 0.07 & <0.05 & 5.46 \\ \text { CC34 } & 0.94 & 6.1 & 342 & 239 & 1.36 & <0.05 & 0.18 & 0.98 \\ \text { CC36 } & 3.27 & 9.6 & 562 & 321 & 12.4 & 0.2 & <0.05 & 2.07 \\ \text { CC38 } & 2.83 & 13.8 & 525 & 972 & 21.3 & 0.1 & <0.05 & 1.38 \\ \text { CC39 } & <0.5 & 5.8 & 283 & 32.9 & <1 & <0.05 & 0.11 & 1.08 \\ \text { CC40 } & <0.5 & 5.9 & 347 & 288 & <1 & 0.05 & 0.19 & 0.88 \\ \text { CC41 } & 1.91 & 9.8 & 575 & 204 & 2.90 & 0.08 & <0.05 & 5.53\end{array}$




\begin{tabular}{|c|c|c|c|c|c|c|c|c|}
\hline Site & K & $\mathrm{Si}$ & Alkalinity & $\mathrm{SO}_{4}$ & $\mathrm{Cl}$ & $\mathrm{F}$ & $\mathrm{N}$ & $\mathrm{Al}$ \\
\hline & $\mathrm{mg} / \mathrm{L}$ & $\mathrm{mg} / \mathrm{L}$ & $\mathrm{mg} / \mathrm{L} \mathrm{HCO}_{3}$ & $\mathrm{mg} / \mathrm{L}$ & $\mathrm{mg} / \mathrm{L}$ & $\mathrm{mg} / \mathrm{L}$ & $\mathrm{mg} / \mathrm{L}$ & $\mu \mathrm{g} / \mathrm{L}$ \\
\hline \multicolumn{9}{|c|}{ Sangre De Cristo Formation in the Sangre de Cristo Range } \\
\hline CC15 & 0.50 & 4.8 & 81 & 1.84 & $<1$ & 0.14 & $<0.05$ & 11.1 \\
\hline $\mathrm{CC} 16$ & $<0.5$ & 6.4 & 177 & 2.59 & $<1$ & 0.07 & $<0.05$ & 2.51 \\
\hline $\mathrm{CC} 17$ & $<0.5$ & 2.0 & 128 & 11.7 & $<1$ & $<0.05$ & $<0.05$ & 6.43 \\
\hline $\mathrm{CC} 18$ & $<0.5$ & 1.5 & 141 & 54.9 & $<1$ & $<0.05$ & $<0.05$ & 3.94 \\
\hline $\mathrm{CC} 19$ & $<0.5$ & 1.5 & 158 & 48.3 & $<1$ & $<0.05$ & $<0.05$ & 1.33 \\
\hline $\mathrm{CC} 20$ & $<0.5$ & 5.6 & 263 & 3.39 & $<1$ & $<0.05$ & $<0.05$ & 1.52 \\
\hline $\mathrm{CC} 21$ & $<0.5$ & 2.2 & 155 & 6.46 & $<1$ & $<0.05$ & 0.07 & 2.00 \\
\hline $\mathrm{CC} 22$ & $<0.5$ & 2.3 & 158 & 5.67 & $<1$ & $<0.05$ & $<0.05$ & 0.22 \\
\hline $\mathrm{CC} 23$ & 0.51 & 4.9 & 240 & 3.49 & $<1$ & $<0.05$ & $<0.05$ & 0.49 \\
\hline $\mathrm{CC} 24$ & 0.55 & 4.8 & 266 & 2.78 & $<1$ & $<0.05$ & $<0.05$ & 1.01 \\
\hline $\mathrm{CC} 25$ & 0.57 & 6.6 & 359 & 6.03 & $<1$ & $<0.05$ & $<0.05$ & 0.48 \\
\hline \multicolumn{9}{|c|}{ Eby and Beaver Creeks } \\
\hline $\mathrm{CC} 32$ & $<0.5$ & 4.0 & 78 & 2.15 & $<1$ & $<0.05$ & $<0.05$ & 11.9 \\
\hline CC37 & 2.05 & 8.8 & 524 & 93.6 & 3.05 & 0.17 & $<0.05$ & 1.24 \\
\hline
\end{tabular}


Appendix 1. Chemical analyses of waters from areas underlain by Permian and Pennsylvanian rocks, western Colorado. (PPsc) Sangre de CristoFormation, (PPwm) Weber Sandstone and Maroon Formation, (Pee) Evaporitic Facies, (Pe) Eagle Valley Formation, (Pmbe) Evaporitic Facies, (Pm) Minturn Formation, (Pmb) Minturn and Belden Formations, (MDr) Missippian and Devonian rocks, and (PC) Precambirian rocks (Tweto, 1979).

\begin{tabular}{|c|c|c|c|c|c|c|c|c|}
\hline Site & $\mathrm{Fe}$ & $\mathrm{Mn}$ & $\mathrm{P}$ & $\mathrm{Li} \mathrm{ug} / \mathrm{L}$ & Sc ug/L & Ti ug/L & $\mathrm{Vug} / \mathrm{L}$ & Crug \\
\hline & $\mu \mathrm{g} / \mathrm{L}$ & $\mu \mathrm{g} / \mathrm{L}$ & $\mu \mathrm{g} / \mathrm{L}$ & $\mu \mathrm{g} / \mathrm{L}$ & $\mu \mathrm{g} / \mathrm{L}$ & $\mu \mathrm{g} / \mathrm{L}$ & $\mu \mathrm{g} / \mathrm{L}$ & $\mu \mathrm{g} / \mathrm{I}$ \\
\hline \multicolumn{9}{|c|}{ Minturn and Belden Formations in the Redcliff Area } \\
\hline $\mathrm{CC} 05$ & 0.002 & 0.1 & $<0.01$ & 4.1 & 0.9 & $<0.1$ & 0.3 & \\
\hline $\mathrm{CC} 06$ & 0.002 & 0.3 & $<0.01$ & 3.7 & 1.1 & 1.3 & 0.4 & \\
\hline $\mathrm{CC} 07$ & $<0.001$ & 0.3 & $<0.01$ & 2.4 & 0.7 & $<0.1$ & 0.3 & \\
\hline $\mathrm{CC} 08$ & 0.002 & 2.8 & $<0.01$ & 2.8 & 0.7 & 0.1 & 0.3 & \\
\hline CC09 & $<0.001$ & 0.1 & $<0.01$ & 2.1 & 0.6 & 0.1 & 0.3 & \\
\hline CC10 & 0.002 & 4.2 & $<0.01$ & 2.0 & 0.6 & $<0.1$ & 0.3 & \\
\hline $\mathrm{CC} 11$ & $<0.001$ & 0.08 & $<0.01$ & 1.3 & 0.6 & $<0.1$ & 0.4 & \\
\hline
\end{tabular}

Minturn and Belden Formations in the Flat Tops Area

$\begin{array}{lcccccccr}\text { CC43 } & 0.002 & 0.9 & <0.01 & 2.8 & 1.1 & 2.1 & 1.1 & 2.8 \\ \text { CC44 } & 0.002 & 0.2 & <0.01 & 2.9 & 1.1 & 1.8 & 1.0 & 2.3 \\ \text { CC45 } & 0.014 & 12.7 & <0.01 & 0.3 & 0.8 & 0.2 & 1.7 & 2.4 \\ \text { CC46 } & <0.001 & 0.2 & 0.019 & 0.5 & 0.8 & <0.1 & 1.4 & 2.5 \\ \text { CC47 } & 0.005 & 10.3 & 0.011 & 0.8 & 0.9 & <0.1 & 2.1 & 2.4 \\ \text { CC48 } & 0.005 & 3.8 & 0.016 & 0.3 & 0.8 & <0.1 & 1.7 & 2.8 \\ \text { CC49 } & <0.001 & 3.7 & 0.014 & 0.3 & 0.9 & <0.1 & 2.5 & 2.6 \\ \text { CC50 } & <0.001 & 0.02 & 0.018 & 0.3 & 0.9 & <0.1 & 2.6 & 2.1\end{array}$

Minturn and Belden Formations in the Sangre de Cristo Range

$\begin{array}{lllllllll}\text { CC13 } & 0.002 & 0.3 & <0.01 & 4.1 & 1.0 & 0.8 & 0.4 & 3.2 \\ \text { CC14 } & 0.001 & 0.4 & <0.01 & 1.0 & 0.7 & 0.4 & 0.7 & 1.0 \\ \text { CC26 } & 0.002 & 0.2 & <0.01 & 4.0 & 1.1 & 4.5 & 0.4 & <1 \\ \text { CC27 } & 0.002 & 0.2 & <0.01 & 4.5 & 1.1 & 2.2 & 0.4 & <1 \\ \text { CC28 } & 0.004 & 1.0 & 0.017 & 1.4 & 1.5 & 1.4 & 0.7 & 1.0 \\ \text { CC29 } & 0.005 & 7.6 & 0.019 & 0.5 & 1.4 & 1.6 & 0.6 & <1\end{array}$

\section{Evaporite Facies of Eagle Valley and South Park}

$\begin{array}{lcccccccc}\text { CC01 } & 0.016 & 57.2 & <0.01 & 110 & 2.8 & 7.6 & 0.9 & 1.7 \\ \text { CC02 } & 0.003 & 4.4 & <0.01 & 1.3 & 2.0 & <0.1 & 2.1 & 1.6 \\ \text { CC03 } & 0.002 & 3.2 & <0.01 & 1.4 & 1.5 & 1.2 & 3.2 & <1 \\ \text { CC31 } & 0.015 & 6.3 & <0.01 & 5.9 & 1.0 & 0.3 & 0.4 & <1 \\ \text { CC33 } & 0.019 & 12.9 & <0.01 & 7.9 & 1.0 & 3.4 & 0.4 & <1 \\ \text { CC34 } & 0.003 & 0.8 & <0.01 & 2.4 & 1.4 & 3.5 & 2.7 & <1 \\ \text { CC36 } & 0.019 & 7.1 & <0.01 & 18.1 & 2.2 & 5.2 & 1.8 & 1.2 \\ \text { CC38 } & 0.020 & 441 & <0.01 & 16.8 & 3.4 & 15.3 & 0.7 & 1.0 \\ \text { CC39 } & 0.001 & 0.1 & 0.030 & <0.1 & 1.6 & 0.4 & 2.8 & <1 \\ \text { CC40 } & 0.002 & 0.06 & 0.011 & 1.2 & 1.4 & 4.2 & 1.1 & <1 \\ \text { CC41 } & 0.016 & 6.3 & 0.023 & 6.7 & 2.0 & 2.8 & 2.7 & 3.8\end{array}$




\begin{tabular}{|c|c|c|c|c|c|c|c|c|}
\hline Site & $\mathrm{Fe}$ & $\mathrm{Mn}$ & $\mathrm{P}$ & $\mathrm{Li}$ ug/L & $\mathrm{Sc} u g / \mathrm{L}$ & $\mathrm{Ti}$ ug/L & V ug/L & $\mathrm{Cr} u g / \mathrm{L}$ \\
\hline & $\mu \mathrm{g} / \mathrm{L}$ & $\mu \mathrm{g} / \mathrm{L}$ & $\mu \mathrm{g} / \mathrm{L}$ & $\mu \mathrm{g} / \mathrm{L}$ & $\mu \mathrm{g} / \mathrm{L}$ & $\mu \mathrm{g} / \mathrm{L}$ & $\mu \mathrm{g} / \mathrm{L}$ & $\mu \mathrm{g} / \mathrm{L}$ \\
\hline \multicolumn{9}{|c|}{ Sangre De Cristo Formation in the Sangre de Cristo Range } \\
\hline $\mathrm{CC} 15$ & 0.012 & 1.0 & $<0.01$ & 0.6 & 0.8 & 0.5 & 0.4 & $<1$ \\
\hline $\mathrm{CC} 16$ & 0.002 & 1.2 & 0.013 & 1.0 & 1.2 & 0.5 & 1.0 & $<1$ \\
\hline $\mathrm{CC} 17$ & 0.016 & 0.7 & $<0.01$ & 0.8 & 0.4 & 0.6 & 0.3 & $<1$ \\
\hline $\mathrm{CC} 18$ & 0.004 & 4.4 & $<0.01$ & 1.1 & 0.4 & 1.1 & 0.2 & $<1$ \\
\hline CC19 & $<0.001$ & 0.2 & $<0.01$ & 1.1 & 0.4 & 1.0 & 0.2 & $<1$ \\
\hline $\mathrm{CC} 20$ & $<0.001$ & 0.4 & $<0.01$ & 1.6 & 1.1 & 0.3 & 0.4 & $<1$ \\
\hline $\mathrm{CC} 21$ & 0.001 & 0.2 & $<0.01$ & 1.0 & 0.4 & 0.4 & 0.2 & $<1$ \\
\hline $\mathrm{CC} 22$ & $<0.001$ & $<0.01$ & $<0.01$ & 0.6 & 0.5 & $<0.1$ & 1.6 & 5.7 \\
\hline $\mathrm{CC} 23$ & $<0.001$ & 0.07 & $<0.01$ & 1.2 & 1.0 & 1.3 & 0.3 & $<1$ \\
\hline $\mathrm{CC} 24$ & $<0.001$ & 0.4 & $<0.01$ & 0.8 & 1.0 & 0.8 & 0.5 & $<1$ \\
\hline $\mathrm{CC} 25$ & 0.002 & $<0.01$ & $<0.01$ & 3.4 & 1.4 & $<0.1$ & 3.8 & 14.0 \\
\hline \multicolumn{9}{|c|}{ Eby and Beaver Creeks } \\
\hline $\mathrm{CC} 32$ & 0.024 & 1.1 & $<0.01$ & 0.4 & 0.9 & 0.1 & 0.1 & $<1$ \\
\hline $\mathrm{CC} 37$ & 0.009 & 22.8 & $<0.01$ & 18.1 & 1.9 & 1.2 & 1.5 & 1 \\
\hline
\end{tabular}


Appendix 1. Chemical analyses of waters from areas underlain by Permian and Pennsylvanian rocks, western Colorado. (PPsc) Sangre de CristoFormation, (PPwm) Weber Sandstone and Maroon Formation, (Pee) Evaporitic Facies, (Pe) Eagle Valley Formation, (Pmbe) Evaporitic Facies, (Pm) Minturn Formation, (Pmb) Minturn and Belden Formations, (MDr) Missippian and Devonian rocks, and (PC) Precambirian rocks (Tweto, 1979).

\begin{tabular}{|c|c|c|c|c|c|c|c|c|c|c|}
\hline Site & $\mathrm{Co}$ & $\mathrm{Ni}$ & $\mathrm{Cu}$ & $\mathrm{Zn}$ & $\mathrm{Rb}$ & $\mathrm{Sr}$ & $\mathrm{Y}$ & $\mathrm{Zr}$ & $\mathrm{Nb}$ & Mo \\
\hline & $\mu \mathrm{g} / \mathrm{L}$ & $\mu \mathrm{g} / \mathrm{L}$ & $\mu \mathrm{g} / \mathrm{L}$ & $\mu \mathrm{g} / \mathrm{L}$ & $\mu \mathrm{g} / \mathrm{L}$ & $\mu \mathrm{g} / \mathrm{L}$ & $\mu \mathrm{g} / \mathrm{L}$ & $\mu \mathrm{g} / \mathrm{L}$ & $\mu \mathrm{g} / \mathrm{L}$ & $\mu \mathrm{g} / \mathrm{L}$ \\
\hline \multicolumn{11}{|c|}{ Minturn and Belden Formations in the Redcliff Area } \\
\hline $\mathrm{CC} 05$ & 0.04 & 0.8 & 0.63 & 0.7 & 0.54 & 81.0 & 0.04 & $<0.05$ & $<0.02$ & 0.62 \\
\hline $\mathrm{CC} 06$ & 0.08 & 2.1 & 0.53 & 0.6 & 0.37 & 597 & 0.12 & $<0.05$ & $<0.02$ & 0.85 \\
\hline $\mathrm{CC} 07$ & 0.05 & 1.2 & $<0.5$ & $<0.5$ & 0.31 & 98.4 & 0.03 & $<0.05$ & 0.03 & 1.29 \\
\hline $\mathrm{CC} 08$ & 0.06 & 1.0 & $<0.5$ & $<0.5$ & 0.27 & 61.0 & 0.03 & 0.05 & 0.03 & 0.42 \\
\hline $\mathrm{CC} 09$ & 0.05 & 1.1 & $<0.5$ & $<0.5$ & 0.32 & 85.4 & 0.02 & $<0.05$ & 0.03 & 0.31 \\
\hline CC10 & 0.07 & 1.4 & $<0.5$ & $<0.5$ & 0.30 & 86.2 & 0.01 & $<0.05$ & 0.03 & 0.31 \\
\hline $\mathrm{CC} 11$ & 0.04 & 0.9 & $<0.5$ & $<0.5$ & 0.35 & 52.6 & 0.03 & $<0.05$ & 0.02 & $<0.2$ \\
\hline \multicolumn{11}{|c|}{ Minturn and Belden Formations in the Flat Tops Area } \\
\hline $\mathrm{CC} 43$ & 0.10 & 2.9 & 0.57 & 0.6 & 0.50 & 1030 & 0.10 & $<0.05$ & $<0.02$ & 2.21 \\
\hline $\mathrm{CC} 44$ & 0.09 & 2.5 & 0.50 & $<0.5$ & 0.33 & 1040 & 0.10 & $<0.05$ & $<0.02$ & 2.16 \\
\hline $\mathrm{CC} 45$ & 0.11 & 1.6 & $<0.5$ & $<0.5$ & 0.57 & 53.6 & 0.03 & $<0.05$ & $<0.02$ & 0.42 \\
\hline $\mathrm{CC} 46$ & 0.06 & 1.6 & $<0.5$ & $<0.5$ & 0.34 & 53.4 & 0.02 & $<0.05$ & $<0.02$ & $<0.2$ \\
\hline $\mathrm{CC} 47$ & 0.09 & 2.0 & $<0.5$ & $<0.5$ & 0.77 & 98.3 & 0.02 & $<0.05$ & $<0.02$ & 0.50 \\
\hline $\mathrm{CC} 48$ & 0.07 & 1.7 & $<0.5$ & $<0.5$ & 0.57 & 55.4 & 0.03 & $<0.05$ & $<0.02$ & $<0.2$ \\
\hline CC49 & 0.07 & 1.6 & $<0.5$ & $<0.5$ & 0.29 & 67.6 & 0.07 & $<0.05$ & $<0.02$ & $<0.2$ \\
\hline CC50 & 0.06 & 1.4 & $<0.5$ & $<0.5$ & 0.35 & 59.9 & 0.02 & $<0.05$ & $<0.02$ & $<0.2$ \\
\hline \multicolumn{11}{|c|}{ Minturn and Belden Formations in the Sangre de Cristo Range } \\
\hline $\mathrm{CC} 13$ & 0.04 & 1.0 & $<0.5$ & 18.6 & 0.23 & 198 & 0.01 & $<0.05$ & $<0.02$ & 0.53 \\
\hline $\mathrm{CC} 14$ & 0.03 & 0.9 & $<0.5$ & 0.8 & 0.37 & 120 & 0.01 & $<0.05$ & $<0.02$ & 0.79 \\
\hline $\mathrm{CC} 26$ & 0.07 & 2.3 & 0.50 & 0.6 & 0.90 & 1230 & 0.10 & 0.06 & 0.06 & 2.38 \\
\hline $\mathrm{CC} 27$ & 0.09 & 2.6 & 0.53 & 0.5 & 0.64 & 1310 & 0.12 & $<0.05$ & 0.02 & 2.75 \\
\hline $\mathrm{CC} 28$ & 0.09 & 2.2 & 0.86 & 0.7 & 0.73 & 506 & 0.13 & $<0.05$ & $<0.02$ & 1.80 \\
\hline $\mathrm{CC} 29$ & 0.09 & 2.1 & 0.60 & 0.5 & 1.48 & 572 & 0.10 & 0.05 & $<0.02$ & 8.06 \\
\hline \multicolumn{11}{|c|}{ Evaporite Facies of Eagle Valley and South Park } \\
\hline $\mathrm{CC} 01$ & 0.30 & 6.0 & 1.7 & 2 & 8.43 & 3110 & 0.14 & 0.3 & $<0.02$ & 0.71 \\
\hline $\mathrm{CC} 02$ & 0.08 & 1.6 & 2.2 & 123 & 0.23 & 363 & 0.03 & $<0.05$ & $<0.02$ & 0.46 \\
\hline $\mathrm{CC} 03$ & 0.07 & 1.6 & 0.55 & 0.6 & 0.35 & 828 & 0.16 & $<0.05$ & $<0.02$ & 1.90 \\
\hline CC 31 & 0.06 & 1.1 & 1.4 & 0.9 & 0.64 & 229 & 0.05 & 0.06 & $<0.02$ & 0.74 \\
\hline CC33 & 0.13 & 3.5 & 1.3 & 7.0 & 0.89 & 1280 & 0.11 & 0.05 & $<0.02$ & 1.71 \\
\hline CC34 & 0.13 & 3.9 & 0.79 & 0.7 & 0.32 & 1690 & 0.11 & $<0.05$ & $<0.02$ & 3.25 \\
\hline CC36 & 0.21 & 5.1 & 1.1 & 1 & 0.75 & 2670 & 0.11 & 0.2 & $<0.02$ & 6.86 \\
\hline CC38 & 3.00 & 14.4 & 2.3 & 2.3 & 1.00 & 4720 & 0.13 & 0.2 & $<0.02$ & 8.62 \\
\hline CC39 & 0.04 & 1.2 & $<0.5$ & $<0.5$ & 0.27 & 215 & 0.01 & $<0.05$ & $<0.02$ & 0.83 \\
\hline CC40 & 0.14 & 4.5 & 0.77 & 1 & 0.38 & 1270 & 0.10 & $<0.05$ & $<0.02$ & 2.50 \\
\hline $\mathrm{CC} 41$ & 0.22 & 4.2 & 0.91 & 0.8 & 0.59 & 1340 & 0.14 & 0.08 & $<0.02$ & 2.39 \\
\hline
\end{tabular}




\begin{tabular}{|c|c|c|c|c|c|c|c|c|c|c|}
\hline Site & Co & $\mathrm{Ni}$ & $\mathrm{Cu}$ & $\mathrm{Zn}$ & $\mathrm{Rb}$ & $\mathrm{Sr}$ & $\mathrm{Y}$ & $\mathrm{Zr}$ & $\mathrm{Nb}$ & Mo \\
\hline & $\mu \mathrm{g} / \mathrm{L}$ & $\mu \mathrm{g} / \mathrm{L}$ & $\mu \mathrm{g} / \mathrm{L}$ & $\mu \mathrm{g} / \mathrm{L}$ & $\mu \mathrm{g} / \mathrm{L}$ & $\mu \mathrm{g} / \mathrm{L}$ & $\mu \mathrm{g} / \mathrm{L}$ & $\mu \mathrm{g} / \mathrm{L}$ & $\mu \mathrm{g} / \mathrm{L}$ & $\mu \mathrm{g} / \mathrm{L}$ \\
\hline \multicolumn{11}{|c|}{ Sangre De Cristo Formation in the Sangre de Cristo Range } \\
\hline $\mathrm{CC} 15$ & 0.03 & 0.3 & 0.62 & 1 & 0.42 & 36.4 & 0.09 & 0.06 & $<0.02$ & 0.47 \\
\hline $\mathrm{CC} 16$ & 0.04 & 0.6 & $<0.5$ & $<0.5$ & 0.24 & 79.9 & 0.03 & $<0.05$ & 0.02 & $<0.2$ \\
\hline $\mathrm{CC} 17$ & 0.03 & 0.6 & 0.52 & $<0.5$ & 0.23 & 86.7 & 0.03 & $<0.05$ & $<0.02$ & $<0.2$ \\
\hline CC18 & 0.05 & 1.0 & $<0.5$ & $<0.5$ & 0.28 & 279 & 0.01 & $<0.05$ & $<0.02$ & 0.41 \\
\hline CC19 & 0.04 & 1.0 & $<0.5$ & $<0.5$ & 0.26 & 259 & 0.01 & $<0.05$ & $<0.02$ & 0.30 \\
\hline $\mathrm{CC} 20$ & 0.04 & 0.9 & $<0.5$ & $<0.5$ & 0.20 & 145 & 0.02 & $<0.05$ & $<0.02$ & $<0.2$ \\
\hline $\mathrm{CC} 21$ & 0.03 & 0.7 & 0.54 & $<0.5$ & 0.42 & 86.5 & 0.03 & $<0.05$ & $<0.02$ & $<0.2$ \\
\hline $\mathrm{CC} 22$ & 0.03 & 0.6 & $<0.5$ & $<0.5$ & 0.38 & 81.8 & 0.02 & 0.1 & 0.1 & 0.46 \\
\hline $\mathrm{CC} 23$ & 0.03 & 0.8 & $<0.5$ & $<0.5$ & 0.52 & 132 & 0.01 & $<0.05$ & 0.04 & $<0.2$ \\
\hline $\mathrm{CC} 24$ & 0.05 & 1.0 & $<0.5$ & $<0.5$ & 0.27 & 91.6 & 0.02 & $<0.05$ & 0.02 & $<0.2$ \\
\hline $\mathrm{CC} 25$ & 0.04 & 1.2 & $<0.5$ & $<0.5$ & 0.53 & 364 & 0.08 & 0.1 & 0.1 & 1.38 \\
\hline \multicolumn{11}{|c|}{ Eby and Beaver Creeks } \\
\hline $\mathrm{CC} 32$ & 0.0 & 0.3 & $<0.5$ & 0.80 & 0.44 & 34.30 & 0.08 & 0.05 & $<0.02$ & $<0.2$ \\
\hline CC37 & 0.13 & 3 & 0.6 & 0.5 & 0.54 & 1180 & 0.11 & 0.08 & $<0.02$ & 3.85 \\
\hline
\end{tabular}


Appendix 1. Chemical analyses of waters from areas underlain by Permian and Pennsylvanian rocks, western Colorado. (PPsc) Sangre de CristoFormation, (PPwm) Weber Sandstone and Maroon Formation, (Pee) Evaporitic Facies, (Pe) Eagle Valley Formation, (Pmbe) Evaporitic Facies, (Pm) Minturn Formation, (Pmb) Minturn and Belden Formations, (MDr) Missippian and Devonian rocks, and (PC) Precambirian rocks (Tweto, 1979).

\begin{tabular}{|c|c|c|c|c|c|c|c|c|c|c|}
\hline Site & $\mathrm{Sb}$ & Cs & $\mathrm{Ba}$ & $\mathrm{La}$ & $\mathrm{Ce}$ & $\operatorname{Pr}$ & $\mathrm{Nd}$ & $\mathrm{Sm}$ & $\mathrm{Eu}$ & $\mathrm{Tb}$ \\
\hline & $\mu \mathrm{g} / \mathrm{L}$ & $\mu \mathrm{g} / \mathrm{L}$ & $\mu \mathrm{g} / \mathrm{L}$ & $\mu \mathrm{g} / \mathrm{L}$ & $\mu \mathrm{g} / \mathrm{L}$ & $\mu \mathrm{g} / \mathrm{L}$ & $\mu \mathrm{g} / \mathrm{L}$ & $\mu \mathrm{g} / \mathrm{L}$ & $\mu \mathrm{g} / \mathrm{L}$ & $\mu \mathrm{g} / \mathrm{L}$ \\
\hline \multicolumn{11}{|c|}{ Minturn and Belden Formations in the Redcliff Area } \\
\hline $\mathrm{CC} 05$ & $<0.1$ & $<0.01$ & 167 & $<0.01$ & $<0.01$ & $<0.01$ & $<0.01$ & $<0.01$ & 0.02 & $<0.005$ \\
\hline $\mathrm{CC} 06$ & $<0.1$ & $<0.01$ & 65.5 & $<0.01$ & $<0.01$ & $<0.01$ & $<0.01$ & $<0.01$ & 0.007 & $<0.005$ \\
\hline $\mathrm{CC} 07$ & 0.1 & $<0.01$ & 73.6 & $<0.01$ & $<0.01$ & $<0.01$ & 0.01 & $<0.01$ & 0.008 & $<0.005$ \\
\hline $\mathrm{CC} 08$ & $<0.1$ & $<0.01$ & 86.3 & $<0.01$ & $<0.01$ & $<0.01$ & 0.01 & $<0.01$ & 0.008 & $<0.005$ \\
\hline $\mathrm{CC} 09$ & $<0.1$ & $<0.01$ & 66.0 & $<0.01$ & $<0.01$ & $<0.01$ & 0.01 & $<0.01$ & 0.008 & $<0.005$ \\
\hline $\mathrm{CC} 10$ & $<0.1$ & $<0.01$ & 62.0 & $<0.01$ & $<0.01$ & $<0.01$ & $<0.01$ & $<0.01$ & 0.007 & $<0.005$ \\
\hline $\mathrm{CC} 11$ & $<0.1$ & $<0.01$ & 85.8 & 0.01 & $<0.01$ & $<0.01$ & 0.02 & $<0.01$ & 0.01 & $<0.005$ \\
\hline \multicolumn{11}{|c|}{ Minturn and Belden Formations in the Flat Tops Area } \\
\hline $\mathrm{CC} 43$ & $<0.1$ & $<0.01$ & 60.4 & $<0.01$ & $<0.01$ & $<0.01$ & $<0.01$ & $<0.01$ & 0.006 & $<0.005$ \\
\hline $\mathrm{CC} 44$ & $<0.1$ & $<0.01$ & 47.5 & $<0.01$ & $<0.01$ & $<0.01$ & $<0.01$ & $<0.01$ & 0.006 & $<0.005$ \\
\hline CC45 & $<0.1$ & $<0.01$ & 34.6 & 0.01 & 0.03 & $<0.01$ & 0.01 & $<0.01$ & 0.007 & $<0.005$ \\
\hline CC46 & $<0.1$ & $<0.01$ & 39.5 & $<0.01$ & $<0.01$ & $<0.01$ & $<0.01$ & $<0.01$ & $<0.005$ & $<0.005$ \\
\hline $\mathrm{CC} 47$ & $<0.1$ & $<0.01$ & 76.4 & $<0.01$ & 0.01 & $<0.01$ & $<0.01$ & $<0.01$ & 0.01 & $<0.005$ \\
\hline $\mathrm{CC} 48$ & $<0.1$ & $<0.01$ & 34.4 & 0.01 & 0.02 & $<0.01$ & 0.01 & $<0.01$ & 0.006 & $<0.005$ \\
\hline CC49 & $<0.1$ & $<0.01$ & 37.8 & 0.03 & 0.02 & $<0.01$ & 0.03 & $<0.01$ & 0.007 & $<0.005$ \\
\hline CC50 & $<0.1$ & $<0.01$ & 44.7 & $<0.01$ & $<0.01$ & $<0.01$ & $<0.01$ & $<0.01$ & 0.005 & $<0.005$ \\
\hline \multicolumn{11}{|c|}{ Minturn and Belden Formations in the Sangre de Cristo Range } \\
\hline $\mathrm{CC} 13$ & $<0.1$ & $<0.01$ & 46.9 & $<0.01$ & $<0.01$ & $<0.01$ & $<0.01$ & $<0.01$ & 0.006 & $<0.005$ \\
\hline $\mathrm{CC} 14$ & $<0.1$ & $<0.01$ & 47.0 & $<0.01$ & $<0.01$ & $<0.01$ & $<0.01$ & $<0.01$ & 0.006 & $<0.005$ \\
\hline $\mathrm{CC} 26$ & $<0.1$ & $<0.01$ & 39.6 & $<0.01$ & $<0.01$ & $<0.01$ & $<0.01$ & $<0.01$ & 0.006 & $<0.005$ \\
\hline $\mathrm{CC} 27$ & 0.2 & $<0.01$ & 38.2 & $<0.01$ & $<0.01$ & $<0.01$ & 0.01 & $<0.01$ & 0.005 & $<0.005$ \\
\hline $\mathrm{CC} 28$ & $<0.1$ & $<0.01$ & 39.6 & $<0.01$ & 0.02 & $<0.01$ & 0.01 & $<0.01$ & 0.005 & $<0.005$ \\
\hline $\mathrm{CC} 29$ & $<0.1$ & $<0.01$ & 42.8 & $<0.01$ & 0.01 & $<0.01$ & 0.02 & $<0.01$ & $<0.005$ & $<0.005$ \\
\hline \multicolumn{11}{|c|}{ Evaporite Facies of Eagle Valley and South Park } \\
\hline $\mathrm{CC} 01$ & $<0.1$ & $<0.01$ & 71.6 & $<0.01$ & 0.02 & $<0.01$ & 0.02 & $<0.01$ & 0.009 & $<0.005$ \\
\hline $\mathrm{CC} 02$ & $<0.1$ & $<0.01$ & 104 & $<0.01$ & $<0.01$ & $<0.01$ & $<0.01$ & $<0.01$ & 0.01 & $<0.005$ \\
\hline $\mathrm{CC} 03$ & $<0.1$ & $<0.01$ & 40.1 & 0.02 & 0.05 & $<0.01$ & 0.02 & $<0.01$ & 0.007 & $<0.005$ \\
\hline CC 31 & $<0.1$ & $<0.01$ & 36.1 & 0.03 & 0.03 & 0.01 & 0.04 & 0.01 & 0.007 & $<0.005$ \\
\hline CC33 & $<0.1$ & $<0.01$ & 53.4 & 0.02 & 0.03 & $<0.01$ & 0.03 & $<0.01$ & 0.007 & $<0.005$ \\
\hline CC34 & $<0.1$ & $<0.01$ & 116 & $<0.01$ & $<0.01$ & $<0.01$ & $<0.01$ & $<0.01$ & 0.02 & $<0.005$ \\
\hline CC36 & 0.1 & $<0.01$ & 55.3 & $<0.01$ & 0.01 & $<0.01$ & $<0.01$ & $<0.01$ & 0.007 & $<0.005$ \\
\hline CC38 & $<0.1$ & $<0.01$ & 34.2 & 0.01 & 0.03 & $<0.01$ & $<0.01$ & $<0.01$ & 0.005 & $<0.005$ \\
\hline CC39 & $<0.1$ & $<0.01$ & 72.5 & $<0.01$ & $<0.01$ & $<0.01$ & $<0.01$ & $<0.01$ & 0.007 & $<0.005$ \\
\hline CC40 & $<0.1$ & $<0.01$ & 19.5 & $<0.01$ & $<0.01$ & $<0.01$ & $<0.01$ & $<0.01$ & 0.005 & $<0.005$ \\
\hline $\mathrm{CC} 41$ & $<0.1$ & $<0.01$ & 92.7 & 0.01 & 0.03 & $<0.01$ & 0.02 & $<0.01$ & 0.01 & $<0.005$ \\
\hline
\end{tabular}




\begin{tabular}{|c|c|c|c|c|c|c|c|c|c|c|}
\hline Site & $\mathrm{Sb}$ & Cs & $\mathrm{Ba}$ & $\mathrm{La}$ & $\mathrm{Ce}$ & $\operatorname{Pr}$ & $\mathrm{Nd}$ & $\mathrm{Sm}$ & $\mathrm{Eu}$ & $\mathrm{Tb}$ \\
\hline & $\mu \mathrm{g} / \mathrm{L}$ & $\mu \mathrm{g} / \mathrm{L}$ & $\mu \mathrm{g} / \mathrm{L}$ & $\mu \mathrm{g} / \mathrm{L}$ & $\mu \mathrm{g} / \mathrm{L}$ & $\mu \mathrm{g} / \mathrm{L}$ & $\mu \mathrm{g} / \mathrm{L}$ & $\mu \mathrm{g} / \mathrm{L}$ & $\mu \mathrm{g} / \mathrm{L}$ & $\mu \mathrm{g} / \mathrm{L}$ \\
\hline \multicolumn{11}{|c|}{ Sangre De Cristo Formation in the Sangre de Cristo Range } \\
\hline $\mathrm{CC} 15$ & $<0.1$ & $<0.01$ & 14.8 & 0.05 & 0.04 & 0.01 & 0.06 & $<0.01$ & 0.005 & $<0.005$ \\
\hline $\mathrm{CC} 16$ & $<0.1$ & $<0.01$ & 64.2 & 0.01 & 0.01 & $<0.01$ & 0.01 & $<0.01$ & 0.007 & $<0.005$ \\
\hline $\mathrm{CC} 17$ & $<0.1$ & $<0.01$ & 48.2 & 0.02 & 0.02 & $<0.01$ & 0.02 & 0.01 & 0.007 & $<0.005$ \\
\hline $\mathrm{CC} 18$ & $<0.1$ & $<0.01$ & 25.8 & $<0.01$ & $<0.01$ & $<0.01$ & $<0.01$ & $<0.01$ & $<0.005$ & $<0.005$ \\
\hline CC19 & $<0.1$ & $<0.01$ & 46.3 & $<0.01$ & $<0.01$ & $<0.01$ & $<0.01$ & $<0.01$ & 0.007 & $<0.005$ \\
\hline CC20 & $<0.1$ & $<0.01$ & 180 & $<0.01$ & $<0.01$ & $<0.01$ & 0.01 & $<0.01$ & 0.02 & $<0.005$ \\
\hline CC21 & $<0.1$ & $<0.01$ & 80.1 & 0.01 & $<0.01$ & $<0.01$ & 0.02 & $<0.01$ & 0.01 & $<0.005$ \\
\hline $\mathrm{CC} 22$ & 0.1 & $<0.01$ & 43.5 & $<0.01$ & $<0.01$ & $<0.01$ & $<0.01$ & $<0.01$ & 0.006 & $<0.005$ \\
\hline $\mathrm{CC} 23$ & $<0.1$ & 0.01 & 121 & $<0.01$ & $<0.01$ & $<0.01$ & $<0.01$ & $<0.01$ & 0.02 & $<0.005$ \\
\hline $\mathrm{CC} 24$ & $<0.1$ & $<0.01$ & 136 & $<0.01$ & $<0.01$ & $<0.01$ & $<0.01$ & $<0.01$ & 0.01 & $<0.005$ \\
\hline $\mathrm{CC} 25$ & 0.64 & $<0.01$ & 186 & $<0.01$ & $<0.01$ & $<0.01$ & $<0.01$ & $<0.01$ & 0.02 & $<0.005$ \\
\hline \multicolumn{11}{|c|}{ Eby and Beaver Creeks } \\
\hline $\mathrm{CC} 32$ & $<0.1$ & $<0.01$ & 20.40 & 0.11 & 0.04 & 0.03 & 0.1 & 0.02 & 0.01 & $<0.005$ \\
\hline $\mathrm{CC} 37$ & $<0.1$ & $<0.01$ & 66.7 & $<0.01$ & $<0.01$ & $<0.01$ & 0.01 & $<0.01$ & 0.008 & $<0.005$ \\
\hline
\end{tabular}


Appendix 1. Chemical analyses of waters from areas underlain by Permian and Pennsylvanian rocks, western Colorado. (PPsc) Sangre de CristoFormation, (PPwm) Weber Sandstone and Maroon Formation, (Pee) Evaporitic Facies, (Pe) Eagle Valley Formation, (Pmbe) Evaporitic Facies, (Pm) Minturn Formation, (Pmb) Minturn and Belden Formations, (MDr) Missippian and Devonian rocks, and (PC) Precambirian rocks (Tweto, 1979).

\begin{tabular}{|c|c|c|c|c|c|c|c|c|}
\hline Site & $\mathrm{Gd}$ & Dy & $\mathrm{Ta}$ & $\mathrm{W}$ & $\mathrm{Pb}$ & $\mathrm{Bi}$ & Th & $\mathrm{U}$ \\
\hline & $\mu \mathrm{g} / \mathrm{L}$ & $\mu \mathrm{g} / \mathrm{L}$ & $\mu \mathrm{g} / \mathrm{L}$ & $\mu \mathrm{g} / \mathrm{L}$ & $\mu \mathrm{g} / \mathrm{L}$ & $\mu \mathrm{g} / \mathrm{L}$ & $\mu \mathrm{g} / \mathrm{L}$ & $\mu \mathrm{g} / \mathrm{L}$ \\
\hline \multicolumn{9}{|c|}{ Minturn and Belden Formations in the Redcliff Area } \\
\hline $\mathrm{CC} 05$ & 0.01 & 0.009 & $<0.02$ & $<0.02$ & $<0.05$ & $<0.005$ & $<0.005$ & 2.13 \\
\hline $\mathrm{CC} 06$ & $<0.005$ & $<0.005$ & $<0.02$ & $<0.02$ & $<0.05$ & $<0.005$ & $<0.005$ & 1.18 \\
\hline $\mathrm{CC} 07$ & 0.005 & $<0.005$ & 0.04 & 0.06 & $<0.05$ & 0.06 & 0.01 & 1.43 \\
\hline $\mathrm{CC} 08$ & 0.005 & $<0.005$ & 0.04 & 0.06 & $<0.05$ & 0.02 & 0.01 & 1.04 \\
\hline $\mathrm{CC} 09$ & $<0.005$ & $<0.005$ & 0.04 & 0.06 & $<0.05$ & 0.01 & 0.008 & 1.23 \\
\hline $\mathrm{CC} 10$ & $<0.005$ & $<0.005$ & 0.03 & 0.05 & $<0.05$ & 0.008 & 0.008 & 1.43 \\
\hline CC11 & 0.005 & $<0.005$ & 0.03 & 0.02 & $<0.05$ & $<0.005$ & $<0.005$ & 1.41 \\
\hline \multicolumn{9}{|c|}{ Minturn and Belden Formations in the Flat Tops Area } \\
\hline $\mathrm{CC} 43$ & $<0.005$ & $<0.005$ & $<0.02$ & 0.02 & $<0.05$ & $<0.005$ & 0.005 & 1.93 \\
\hline $\mathrm{CC} 44$ & $<0.005$ & $<0.005$ & $<0.02$ & $<0.02$ & $<0.05$ & $<0.005$ & $<0.005$ & 2.40 \\
\hline CC45 & $<0.005$ & $<0.005$ & $<0.02$ & $<0.02$ & $<0.05$ & $<0.005$ & $<0.005$ & 1.09 \\
\hline $\mathrm{CC} 46$ & $<0.005$ & $<0.005$ & $<0.02$ & $<0.02$ & $<0.05$ & $<0.005$ & $<0.005$ & 0.49 \\
\hline CC47 & $<0.005$ & $<0.005$ & $<0.02$ & $<0.02$ & $<0.05$ & $<0.005$ & $<0.005$ & 0.97 \\
\hline $\mathrm{CC} 48$ & $<0.005$ & $<0.005$ & $<0.02$ & $<0.02$ & $<0.05$ & $<0.005$ & $<0.005$ & 0.36 \\
\hline CC49 & 0.005 & 0.005 & $<0.02$ & $<0.02$ & $<0.05$ & $<0.005$ & 0.005 & 0.57 \\
\hline CC50 & $<0.005$ & $<0.005$ & $<0.02$ & $<0.02$ & $<0.05$ & $<0.005$ & $<0.005$ & 0.38 \\
\hline \multicolumn{9}{|c|}{ Minturn and Belden Formations in the Sangre de Cristo Range } \\
\hline $\mathrm{CC} 13$ & $<0.005$ & $<0.005$ & 0.02 & 0.03 & $<0.05$ & $<0.005$ & 0.005 & 1.25 \\
\hline $\mathrm{CC} 14$ & $<0.005$ & $<0.005$ & 0.03 & 0.04 & $<0.05$ & $<0.005$ & $<0.005$ & 1.19 \\
\hline $\mathrm{CC} 26$ & $<0.005$ & $<0.005$ & 0.05 & 0.07 & $<0.05$ & $<0.005$ & 0.02 & 1.00 \\
\hline $\mathrm{CC} 27$ & $<0.005$ & $<0.005$ & 0.05 & 0.07 & $<0.05$ & 0.05 & 0.03 & 1.26 \\
\hline $\mathrm{CC} 28$ & $<0.005$ & $<0.005$ & 0.04 & 0.07 & $<0.05$ & 0.02 & 0.02 & 1.81 \\
\hline CC29 & $<0.005$ & $<0.005$ & 0.03 & 0.08 & $<0.05$ & 0.009 & 0.03 & 1.24 \\
\hline \multicolumn{9}{|c|}{ Evaporite Facies of Eagle Valley and South Park } \\
\hline $\mathrm{CC} 01$ & $<0.005$ & $<0.005$ & 0.06 & 0.07 & $<0.05$ & $<0.005$ & 0.05 & 1.16 \\
\hline $\mathrm{CC} 02$ & $<0.005$ & $<0.005$ & $<0.02$ & $<0.02$ & 0.1 & $<0.005$ & $<0.005$ & 1.69 \\
\hline $\mathrm{CC} 03$ & 0.008 & 0.009 & $<0.02$ & $<0.02$ & $<0.05$ & $<0.005$ & 0.005 & 1.62 \\
\hline CC31 & 0.008 & 0.007 & $<0.02$ & 0.04 & $<0.05$ & $<0.005$ & 0.007 & 0.37 \\
\hline CC33 & 0.009 & 0.006 & $<0.02$ & 0.04 & 0.08 & $<0.005$ & 0.03 & 1.45 \\
\hline CC34 & $<0.005$ & $<0.005$ & $<0.02$ & $<0.02$ & $<0.05$ & $<0.005$ & 0.02 & 1.93 \\
\hline $\mathrm{CC} 36$ & $<0.005$ & $<0.005$ & $<0.02$ & 0.03 & $<0.05$ & $<0.005$ & 0.04 & 6.12 \\
\hline CC38 & $<0.005$ & $<0.005$ & $<0.02$ & 0.03 & $<0.05$ & $<0.005$ & 0.14 & 4.57 \\
\hline CC39 & $<0.005$ & $<0.005$ & $<0.02$ & $<0.02$ & $<0.05$ & $<0.005$ & $<0.005$ & 0.44 \\
\hline $\mathrm{CC} 40$ & $<0.005$ & $<0.005$ & $<0.02$ & $<0.02$ & $<0.05$ & $<0.005$ & 0.008 & 1.04 \\
\hline CC41 & 0.006 & 0.006 & 0.03 & 0.04 & $<0.05$ & $<0.005$ & 0.01 & 1.45 \\
\hline
\end{tabular}




\begin{tabular}{|c|c|c|c|c|c|c|c|c|}
\hline Site & $\mathrm{Gd}$ & Dy & $\mathrm{Ta}$ & $\mathrm{W}$ & $\mathrm{Pb}$ & $\mathrm{Bi}$ & Th & $\mathrm{U}$ \\
\hline & $\mu \mathrm{g} / \mathrm{L}$ & $\mu \mathrm{g} / \mathrm{L}$ & $\mu \mathrm{g} / \mathrm{L}$ & $\mu \mathrm{g} / \mathrm{L}$ & $\mu \mathrm{g} / \mathrm{L}$ & $\mu \mathrm{g} / \mathrm{L}$ & $\mu \mathrm{g} / \mathrm{L}$ & $\mu \mathrm{g} / \mathrm{L}$ \\
\hline \multicolumn{9}{|c|}{ Sangre De Cristo Formation in the Sangre de Cristo Range } \\
\hline CC15 & 0.02 & 0.01 & 0.03 & 0.03 & $<0.05$ & $<0.005$ & 0.01 & 0.03 \\
\hline CC16 & 0.006 & $<0.005$ & 0.03 & $<0.02$ & $<0.05$ & $<0.005$ & 0.007 & 0.20 \\
\hline $\mathrm{CC} 17$ & 0.007 & 0.005 & 0.02 & 0.02 & $<0.05$ & $<0.005$ & 0.006 & 0.32 \\
\hline $\mathrm{CC} 18$ & $<0.005$ & $<0.005$ & $<0.02$ & 0.02 & $<0.05$ & $<0.005$ & 0.007 & 0.48 \\
\hline $\mathrm{CC} 19$ & $<0.005$ & $<0.005$ & $<0.02$ & $<0.02$ & $<0.05$ & $<0.005$ & $<0.005$ & 0.28 \\
\hline $\mathrm{CC} 20$ & $<0.005$ & $<0.005$ & $<0.02$ & 0.03 & $<0.05$ & $<0.005$ & $<0.005$ & 0.25 \\
\hline $\mathrm{CC} 21$ & $<0.005$ & $<0.005$ & $<0.02$ & $<0.02$ & $<0.05$ & $<0.005$ & $<0.005$ & 0.43 \\
\hline $\mathrm{CC} 22$ & $<0.005$ & $<0.005$ & 0.08 & 0.51 & $<0.05$ & $<0.005$ & 0.007 & 0.21 \\
\hline $\mathrm{CC} 23$ & $<0.005$ & $<0.005$ & 0.03 & 0.05 & $<0.05$ & $<0.005$ & $<0.005$ & 0.62 \\
\hline $\mathrm{CC} 24$ & $<0.005$ & $<0.005$ & 0.03 & $<0.02$ & $<0.05$ & $<0.005$ & $<0.005$ & 1.59 \\
\hline $\mathrm{CC} 25$ & $<0.005$ & $<0.005$ & 0.09 & 0.44 & $<0.05$ & $<0.005$ & $<0.005$ & 1.94 \\
\hline \multicolumn{9}{|c|}{ Eby and Beaver Creeks } \\
\hline CC32 & 0.02 & 0.01 & $<0.02$ & $<0.02$ & $<0.05$ & $<0.005$ & 0.008 & 0.06 \\
\hline CC 37 & $<0.005$ & $<0.005$ & $<0.02$ & $<0.02$ & $<0.05$ & $<0.005$ & 0.009 & 2.42 \\
\hline
\end{tabular}

